\title{
Making the Most of a Bad Situation? Glastonbury Abbey, Meare, and the Medieval Exploitation of Wetland Resources in the Somerset Levels
}

\author{
By STEPHEN RIPPON
}

\begin{abstract}
MEARE, famous for its 'Abbot's Fish House', lay at the centre of Glastonbury Abbey's estates in Somerset. This paper reconstructs the medieval landscape that surrounded it, in particular showing how highly valued wetland resources were. A strongly interdisciplinary approach is used, integrating remarkably rich documentary material with evidence contained within the 'historic landscape': the pattern offields, roads, settlements and watercourses as represented on the earliest (early I gth-century) cartographic sources and in many cases still in use today. Historic landscape characterization allows a series of distinctive 'landscape character areas' to be identified which reflect the impact that both lordship and community had on the landscape, with a walled manorial complex, adjacent church, planned village, carefully laid out open fields, and areas of reclaimed meadow, surrounded by extensive common pastures and the famous Meare Pool. These wetlands were clearly highly valued, both materially, as demonstrated by a series of acrimonious disputes between Glastonbury and the Dean and Chapter of Wells Cathedral over their respective rights there, and symbolically, as reflected in the inclusion of Meare along with a series of other islands and their associated Christian sites in the special jurisdiction known as the 'Twelve Hides'. Key to the successful utilization of this landscape was the control of water as a resource, including the exploitation of its natural occurrence in Meare Pool, and its manipulation in the form of canals used for navigation, fishing, flood prevention, and powering mills.
\end{abstract}

The significance of monasteries in shaping the medieval landscape has long been recognized, and their role in managing water and reclaiming wetlands, reflecting the increasing intensity with which the landscape was exploited during the High Middle Ages, is relatively well known. ${ }^{1}$ In a society that now values agricultural production so highly, and in the light of the almost relentless trend towards reclamation during the medieval and post-medieval period, it is, however, easy to overlook the significance of the natural resources that wetlands have to offer. These

\footnotetext{
${ }^{1}$ E.g. J. Bond, 'Monastic water management in Great Britain: a review', 88-136 in G. Keevill, M. Aston, and T. Hall (eds.), Monastic Archaeology (Oxford, 200 I); H. C. Darby, Medieval Fenland (Cambridge, I 940); R. A. Donkin, 'The marshland holdings of the English Cistercians before $c$. I350, Citeaux in de Nederlanden, 9 (1958), 262-75; S. Rippon, The Transformation of Coastal Wetlands (London, 2000).
} 
resources can only be understood in their wider landscape context. Artefacts recovered from the recent excavation of two platforms next to Whittlesey Mere in Fenland, for example, have shed important light on medieval fishing techniques, but there is little attempt at palaeogeographical mapping in order to reconstruct the wider seigniorial landscape within which the fishery was but just one element. ${ }^{2}$ This study is an attempt to achieve this for another wetland area: the manor of Meare in the eastern backfens of the Somerset Levels. It does not attempt to provide a definitive landscape history of the area, but focuses on a specific theme: the perception of a major landowning institution, Glastonbury Abbey, towards a landscape dominated by water, and its approach toward utilizing such a difficult environment.

By the Early-medieval Period, the Somerset Levels encompassed an ecological mosaic, with intertidal marshes towards the coast, and extensive freshwater peatlands in the lower-lying backfens (Figs. I-3). These different wetlands offered a range of natural resources that human communities had exploited since prehistoric and Romano-British times ${ }^{3}$ and in this paper their utilization during the medieval period is reconstructed as a contribution to understanding the increasing intensity with which the English landscape was used during the High Middle Ages. Lying in the peat-dominated 'moors' and 'heaths' of the Brue Valley, this area was amongst the most poorly drained areas of the Somerset Levels, and as such it might be expected that, until their comprehensive drainage in the I 8th century, such areas were perceived as being of little value. The derogatory accounts of wetlands generally found in post-medieval topographical and agricultural writings would appear to confirm that impression, ${ }^{4}$ but this paper will show how medieval perceptions of these environments were, in contrast, very different and that Meare was far from being regarded as occupying a 'bad situation'.

\section{UNRAVELLING THE LANDSGAPE HISTORY OF MEARE AND THE BRUE VALLEY}

Glastonbury Abbey dominated the Somerset Levels and the islands within them. One major estate, known in the pre-Conquest period as 'Pouholt', covered the Polden Hills, a long peninsula of bedrock that extended out into the wetlands west of Glastonbury. ${ }^{5}$ The medieval landscape of the Poldens was one of nucleated villages and open fields, which along with a number of other estates in Somerset, may have been laid out during the i oth century. ${ }^{6}$ The landscape surrounding the

\footnotetext{
${ }^{2}$ G. Lucas, 'A medieval fishery on Whittlesea Mere, Cambridgeshire', Medieval Archaeol., XLII ( I 998), i 9-44.

3 B. Coles and J. Coles, Sweet Track to Glastonbury (London, I 986); S. Rippon, The Severn Estuary: Landscape Evolution and Wetland Reclamation (London, i997).

${ }^{4}$ S. Rippon, 'Fields of beans and flocks of sheep: the perception of wetland landscapes during the medieval period', in M. Bell and J. Boardman (eds.), Geoarchaeology: Landscape Change Over Archaeological Timescales (Oxford, forthcoming).

${ }^{5}$ L. Abrams, Anglo-Saxon Glastonbury: Church and Endowment (Woodbridge, i996), map 6; S. C. Morland, 'The Saxon charters for Sowy and Pouholt', Somerset Dorset Notes Queries, 3 I ( I 982), 233-5.

${ }^{6}$ M. Aston and C. Gerrard, "Unique, traditional and charming": the Shapwick Project, Somerset', Antiq. 7., 79 ( I 999), I-58; M. D. Costen, 'Some evidence for new settlements and field systems in late Anglo-Saxon Somerset', $39^{-5} 5$ in L. Abrams and J. Carley (eds.), The Archaeology and History of Glastonbury Abbey (Woodbridge, I 99 I); Rippon, op. cit. in note 3, I6o-65; idem, Historic Landscape Analysis: Deciphering the Countryside (York, 2004).
} 


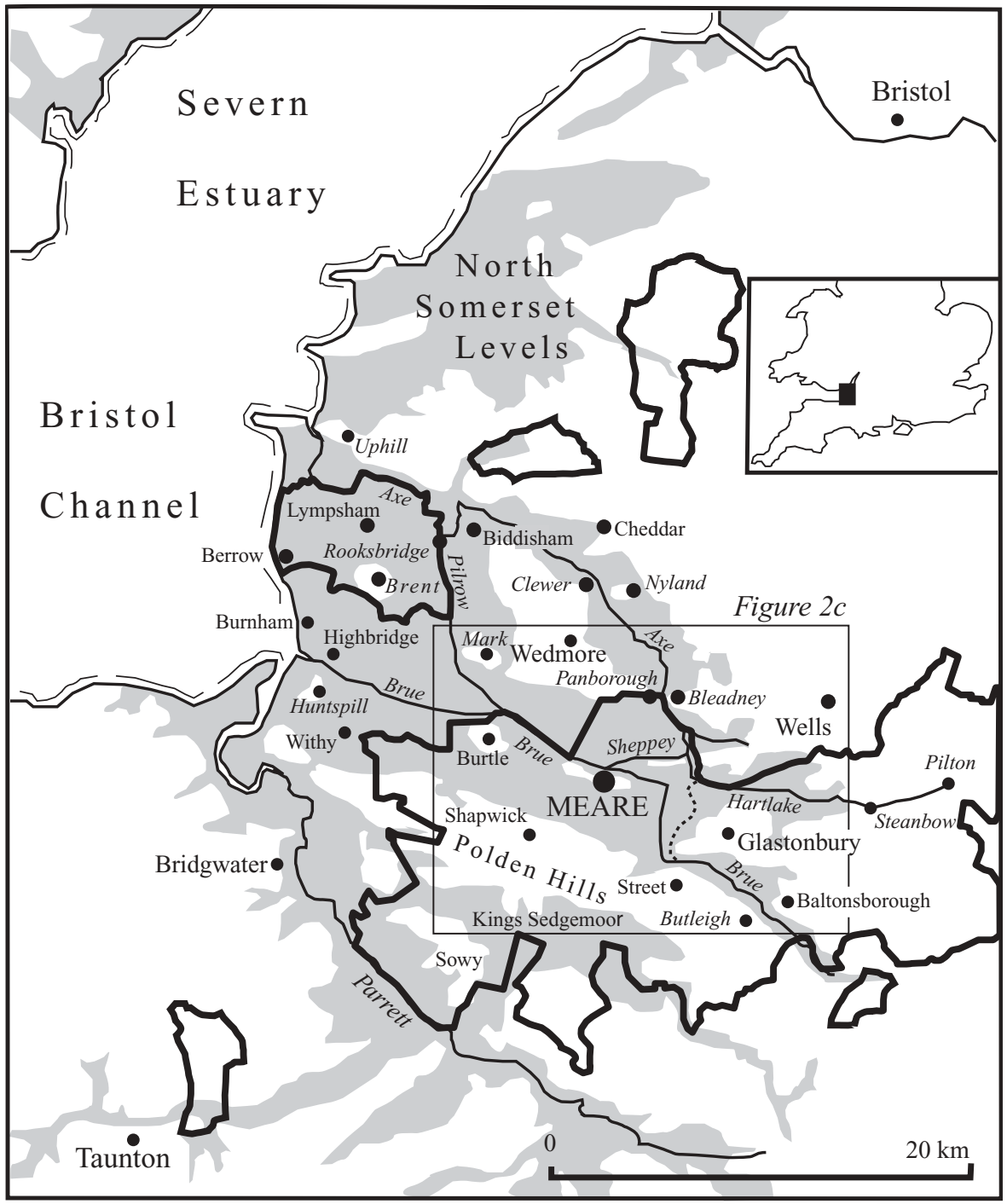

FIG. I

The Somerset Levels, with places that could be reached by boat from Glastonbury in italics, and other features mentioned in the text including the modern river names (the old course of the Brue is shown with a dashed line). The estates of Glastonbury Abbey are outlined in a bold.

Poldens was, however, very different, being dominated by the low-lying wetlands of the Brue Valley to the north including the small islands of Meare and Godney, and Sedgemoor to the south including the island of Sowy.

This is a remarkably well-documented landscape. The charters of Glastonbury Abbey are collected together in the histories compiled by William of Malmesbury (c. I I 29) and John of Glastonbury (c. I 342), the Great Chartulary of c. I 348 (which includes reference to a now lost chartulary the Liber Terrarum), and are discussed by 
Abrams and Morland. ${ }^{7}$ The numbers of these charters in Sawyer are given here as S.oooo. ${ }^{8}$ A series of monastic surveys also survive for i i 89 (Abbot Sully), ${ }^{9}$ I $234 / 5$ (Abbot Amesbury), ${ }^{10}$ I 260 (Abbot Ford), ${ }^{11}$ I 355 (Abbot Monington), ${ }^{12}$ and I 5 I $5 /$ 20 (Abbot Beere), ${ }^{13}$ and its estates were again described at the Dissolution in I 539. ${ }^{14}$ There are also long series of account and court rolls which for Meare cover I 257-I 344 and I262-I532 respectively. ${ }^{15}$ These archives have seen much attention from social and economic historians although the physical structure of the landscape, and the wealth of non-agrarian resources contained within its estates, have received far less attention. ${ }^{16}$ The aim of this paper is to address that imbalance.

Two archives for this area that have received far less attention are those of the Bishop and Dean and Chapter of Wells Cathedral. The Dean and Chapter held the manors of Wedmore and Mudgley on the northern side of the Brue Valley, including Tadham Moor to the north-west of Meare, along with land in the moors north of Glastonbury (Fig. 2). ${ }^{17}$ The Bishop himself held Tealham Moor (west of Tadham Moor) that was part of his manor of Blackford. ${ }^{18}$

The challenge for the landscape archaeologist/historian is to integrate all these disparate sources of evidence through the integration of both the physical

${ }^{7}$ William of Malmesbury's, De Antiquitate Glastonie Ecclesie, ed. and trans. J. Scott, The Early History of Glastonbury: An Edition, Translation and Study of William of Malmesbury's 'De Antiquitate Glastonie Ecclesie' (Woodbridge, ig8 I) [henceforward Malmesbury]; John of Glastonbury, Cronica sive Antiquitates Glastoniensis Eccesie, ed. and trans. J. P. Carley, The Chronicle of Glastonbury Abbey (Woodbridge, i 985) [henceforward f. Glaston.]; D. A. Watkin, The Great Chartulary of Glastonbury, I-III (Somerset Rec. Soc. LIX, I947; LXIII, I952; LXIV, I956) [henceforward G.C. I-III]; Abrams, op. cit. note 5; S. Morland, 'The Glastonbury manors and their Saxon charters', Somerset Archaeol. Nat. Hist., i 30 (1986), 6 $1-$ i 05 .

${ }^{8}$ P. H. Sawyer, Anglo-Saxon Charters: An Annotated List and Bibliography (London, i 968).

${ }^{9}$ Henry Sully, Liber Henrici de Soliaco Abbatis Glaston, ed. J. E. Jackson, An Inquisition of the Manors of Glastonbury Abbey, I I89 (London, I875); and ed. and trans. N. E. Stacy, Surveys of the Estates of Glastonbury Abbey, c. I I35-I20I (London, 200 I) [henceforward Sully].

${ }_{10}$ G. J. Elton, Rentalia et Custumaria: Michaeluis de Ambresbury I235-52 et Rogeri de Ford I252-I26 I (Somerset Rec. Soc. 5, i 89 I) [henceforward Amesbury and Ford respectively].

${ }^{11}$ Ibid.

12 British Library Egerton 332 I: Register and Extents of Abbots I 308-55 (including Monnington).

${ }_{13}$ British Library Egerton 3034 and 3 I 34 : Terrier of Abbot Richard Beere I 5 I $5^{-20}$.

14 'Survey by Richard Pollard and Thomas Moyle, general surveyors of the King's lands, I539', 569-78 in W. Phelps, The History and Antiquities of Somersetshire, I (London, I 836 ).

${ }^{15}$ D. Musgrove, 'The medieval exploitation and reclamation of the inland peat moors in the Somerset Levels', Archaeol. Severn Estuary, 8 ( 1 997), 89-97; idem, The Medieval Exploitation of the Peat Moors of the Somerset Levels (unpub. Ph.D. thesis, Univ. of Exeter, I 999); idem, 'Modelling landscape development in a wetland environment: the medieval peat moors of the Somerset Levels', 227-42 in B. Raftery and J. Hickey (eds.), Recent Developments in Wetland Research (Dublin, 200 I).

${ }^{16}$ Abrams and Carley (eds.), op. cit. in note 6; N. Corcos, The Affinities and Antecedents of Medieval Settlement: Topographical Perspectives from Three of the Somerset Hundreds (Oxford, 2002); M. Ecclestone, Dairy Production on the Glastonbury Abbey Demesne i 256-I 334 (unpub. M.A. diss., Univ. of Bristol, I 996); J. Harrison, The Composite Manor of Brent: a Study of a Large Wetland-edge Estate up to I $35^{\circ}$ (unpub. Ph.D. thesis, Univ. of Leicester, I 997); R. Holt, 'Whose were the profits of milling corn? The abbots of Glastonbury and their tenants i o86-I 350', Past \& Present, I I 6 ( I 986), 3-25; I. J. E. Keil, The Estates of Glastonbury Abbey in the Later Middle Ages (unpub. Ph.D. thesis, Univ. of Bristol, I 964); R. Lennard, 'The demesne of Glastonbury Abbey in the eleventh and twelfth centuries', Economic Hist. Rev., 8 (I955/6), 255-303; M. Postan, 'Glastonbury estates in the twelfth century: a restatement', Economic Hist. Rev., 28 (I975), 524-7; N. E. Stacey, The Estates of Glastonbury Abbey c. I050-I 200 (unpub. Ph.D. thesis, Univ. of Leeds, I 972); M. G. Thompson, The Polden Hill Manors of Glastonbury Abbey: Land and People circa i 26o to I 35 I (unpub. Ph.D. thesis, Univ. of Leicester, I997).

${ }^{17}$ S. Bailey, Wells Manor of Canon Grange (Stroud, I 985 ); W. H. B. Bird, Calendar of the Manuscripts of the Dean and Chapter of Wells, I (London, I 907) [henceforward Wells I]; W. P. Baildon, Calendar of the Manuscripts of the Dean and Chapter of Wells, II (London, I 9 I 4 ) [henceforward Wells II].

${ }_{18}$ P. M. Hembury, The Bishops of Bath and Wells I540-I640: Social and Economic Problems (London, I967); M. Thompson, Medieval Bishop's Houses in England and Wales (Aldershot, I998). 
fabric of the landscape and its nomenclature (field- and place-names). This can be assisted through an analysis of the historic landscape, a technique increasingly used within the planning system (where it is called 'Historic Landscape Characterisation') as a means of understanding the time-depth evident in the present landscape in order to inform decisions made by planners and countryside managers, ${ }^{19}$ but which can also be used to understand the origins and development of the landscape. The spatial configuration of field systems, road networks and settlement patterns shown in the two earliest cartographic representations of Meare, for example (the Brue Valley Drainage Map of 1806 and Tithe Map and Award of I 844), ${ }^{20}$ allows the landscape to be broken down into a series of distinctive types each with a set of 'character defining features', whose morphology is suggestive of the processes that lay behind their creation. By linking the i gth-century field- and place-names with those contained within the monastic records, the medieval landscape can then be reconstructed at different points in time. Initially, however, we must go back to the Early-medieval Period and examine the origins of Meare.

\section{MEARE AND THE EASTERN BRUE VALLEY}

Meare is one of several bedrock islands lying within the wetlands west of Glastonbury (Figs. I-4). Most of the islands (Meare, Godney, Barrow Hill in Panborough, Fenny Castle, Marchey and Nyland) comprise clays, mudstones and limestones of the Mercian Mudstone Group (formerly Keuper Marl), Rhaetic Clay and Lower Lias, while east of Meare lie outcrops of interglacial 'Burtle Bed' sand at Honeygar Farm and Burtle. ${ }^{21}$ Following Godwin's early work around Meare Pool, and Beckett and Hibbert's coring in Meare Heath, ${ }^{22}$ the wetlands of Meare and Godney have seen a number of recent stratigraphic and palaeoenvironmental investigations, notably by Housley and colleagues, Aalbersberg and Somerset County Council. ${ }^{23}$ There are four major wetland deposits around Meare: raised bog peat, fen car/reedswamp peats, estuarine alluvium, and freshwater alluvium (Fig. 3). The oldest of these deposits, west of Burtle, north of Godney and in the Axe Valley, are silty clays of the Upper Wentlooge Formation, giving rise to soils of the 'Wentloog'/Newchurch 2 Series, which were deposited during a ist millennium

\footnotetext{
${ }^{19}$ G. Fairclough and S. Rippon, Europe's Cultural Landscape (Brussels, 200 I).

${ }^{20}$ Somerset Records Office [henceforward SRO] Q/Rde i 2 i; SRO D/D/Rt 423.

${ }^{21}$ The geology and soils of this area have been published at r:50,00o (Geological Survey, and Soil Survey, Sheets 280 and 296 ), with the position of the fen-edge amended in places after fieldwork by the author.

${ }^{22}$ H. Godwin, 'The Meare Pool region of the Somerset Levels', Phil. Trans. Royal Soc. London, Ser. B, 239 (I 955), I 6 I-9o; S. C. Beckett and F. A. Hibbert, 'Vegetational change and the influence of prehistoric man in the Somerset Levels', New Phytologist, 83 ( 1979), 577-6oo.

${ }^{23}$ R. A. Housley, 'The environmental context of Glastonbury Lake Village', Somerset Levels Papers, I4 (I988), 63-82; R. Housley, 'The environment', , 2 I -36 in J. Coles and S. Minnitt (eds.), Industrious and Fairly Civilised: The Glastonbury Lake Village (Taunton, i 995); R. A. Housley, V. Straker and D. W. Cope, 'The Holocene peat and alluvial stratigraphy of the upper Brue Valley in the Somerset levels based on Soil Survey data of the I980s', Archaeol. Severn Estuary, io ( I 999), i I-23; G. Aalbersberg, The Alluvial Fringes of the Somerset Levels (unpub. Ph.D. thesis, Univ. of Exeter, I 999); G. Aalbersberg, A. G. Brown and B. J. Coles, 'Palaeo-hydrology of Late Holocene flooding layers of the Brue Valley (Somerset Levels, Great Britain)', The Holocene, forthcoming; Somerset County Council I992: A Palaeoenvironmental Investigation of a Field off White's Drove, Godney Moor, Near Wells, Somerset: Interim Report (unpubl. rep., Somerset County Council Environment Section, Taunton).
} 

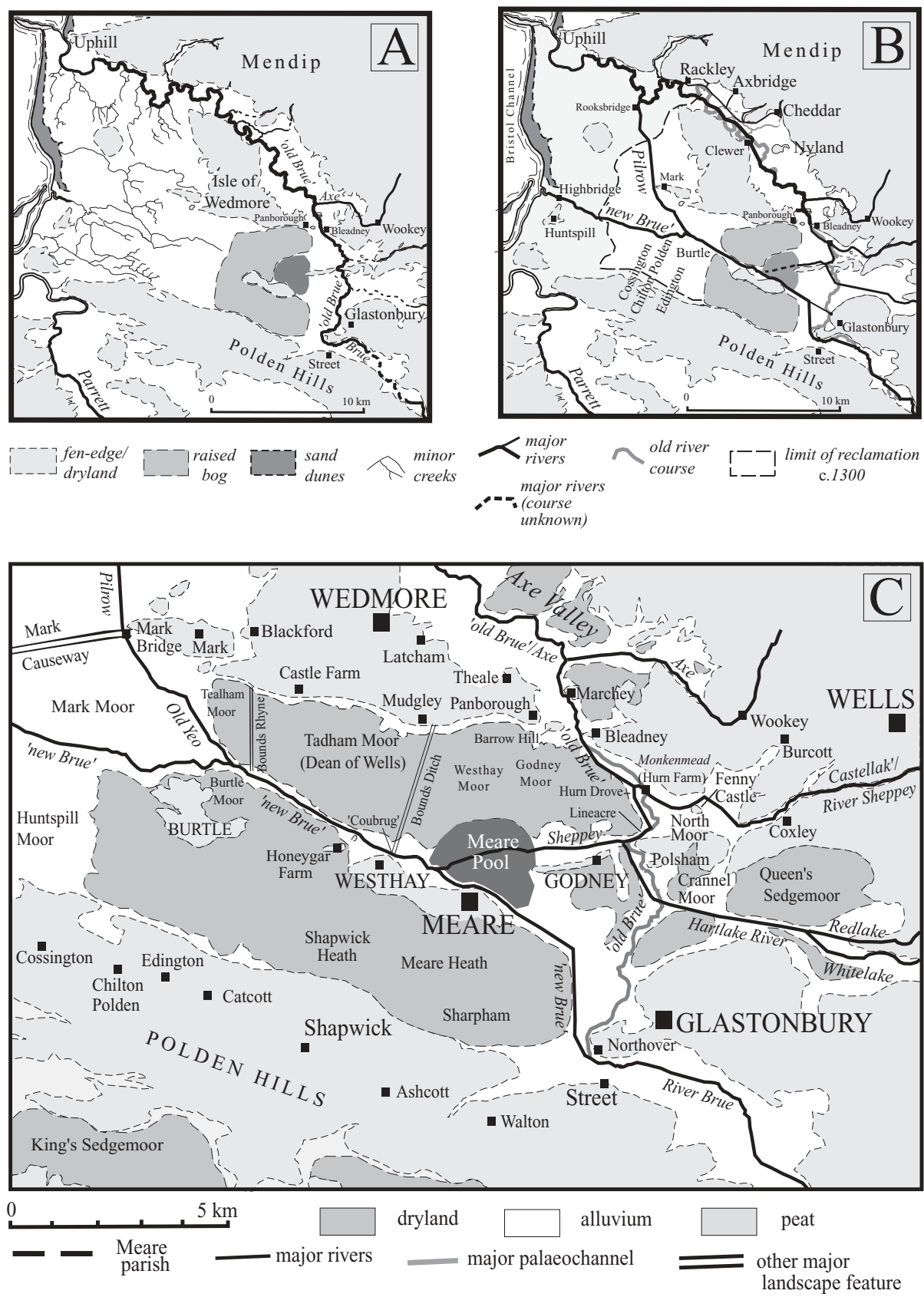

FIG. 2

Evolution of the river and canal system in the Somerset Levels. (A) 'Natural' drainage system in the Earlymedieval Period, showing the 'old Brue Brue' flowing northwards into the Axe Valley between the Isle of Wedmore and Mendip. Based on air photographic evidence for palaeochannel and Aalbersberg, op. cit. note 23, figs. 4. I and 5. I. (B) The Brue diverted westwards past Meare, as were some of the waters of the rivers entering the Levels between Glastonbury and Wells (the Whitelake, Redlake and Sheppey). (C) The Brue

Valley, with major rivers/canals and other key places mentioned in the text. A more detailed mapping of the soils is shown in Figure 3. 


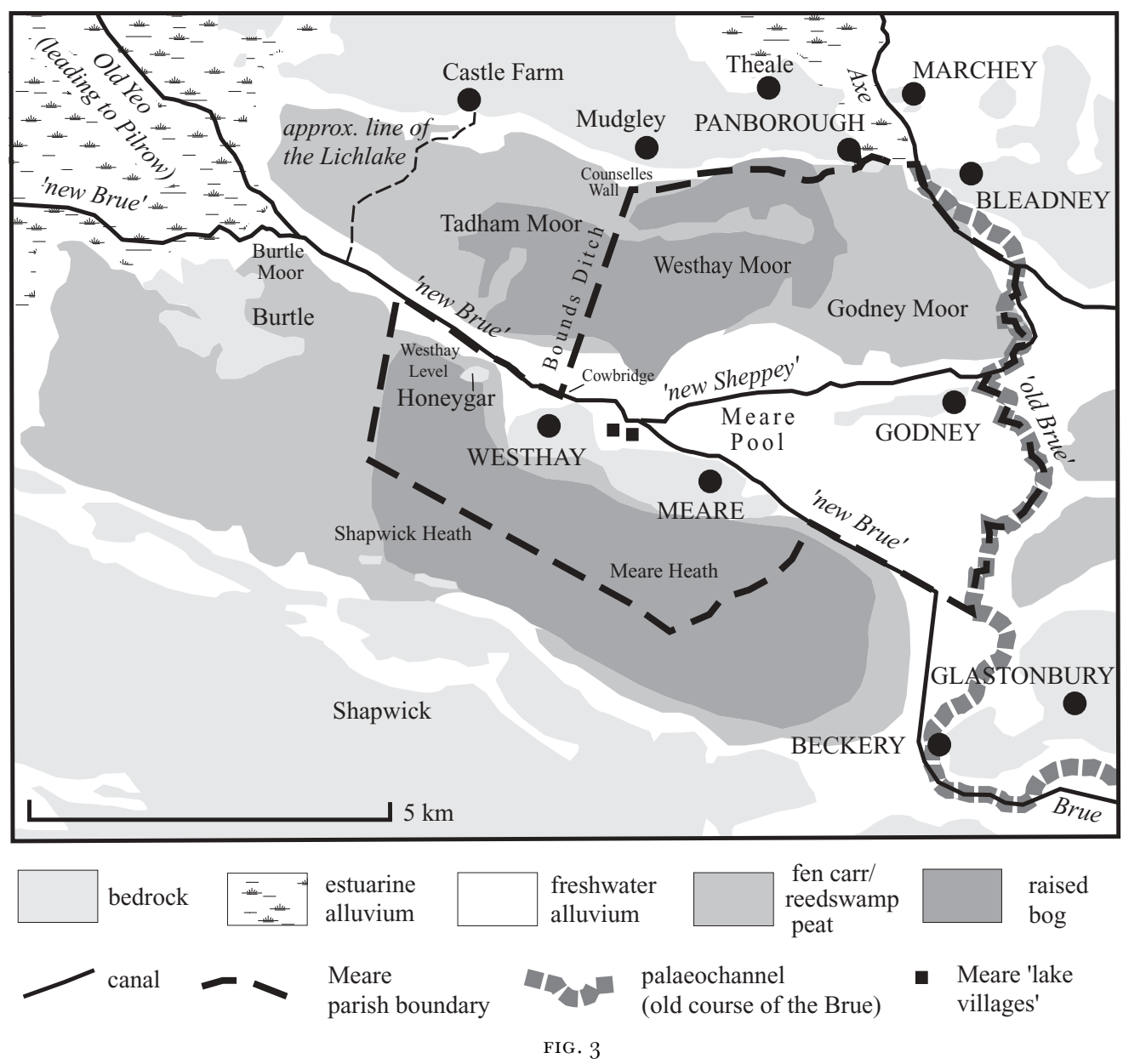

Meare parish/manor and major soil-formations in the Brue and Axe Valleys. Former course of the Brue taken from Aalbersberg, as Figure 2A. The 'islands' of Glastonbury Abbey (some are actually promontories) are labelled in capitals. Note that the contemporary landscape context of the Iron-age Meare 'Lake Villages' was raised bog, which is now sealed by later alluvium deposited after the diversion of the Brue and around the fringes of the medieval Meare Pool.

B.C. marine transgression under saltmarsh conditions. ${ }^{24}$ At the same time areas to the north and south of Meare saw the continued development of raised bogs that lasted until at least the i oth century, ${ }^{25}$ and which were fringed by reedswamp and fen peats. These were particularly extensive around Godney and also continued to form until at least the 8 th to ioth century. ${ }^{26}$ Before peat-cutting, drainage and

\footnotetext{
${ }^{24}$ Aalbersberg, op. cit. in note 23, 90-2 and 198-20 I; D. C. Findlay, The Soils of Mendip District of Somerset (Harpenden, I965); S. K. Haslett et al., 'The changing estuarine environment in relation to Holocene sea-level and the archaeological implications', 35-53 in S. Rippon (ed.), Estuarine Archaeology: The Severn and Beyond (2000); Housley i 988, op. cit. in note 23, 68-70; D. Mackney, J. M. Hodgson, J. M. Hollis and S. J. Staines, Legend for the I:250,00o Soil Map of England and Wales (Harpenden, I983).

25 I $080 \pm 50$ BP, 880- I O20 cal. AD: Somerset County Council, op. cit. in note 23.

${ }^{26}$ I I $70 \pm 60 \mathrm{BP}, 786-968$ cal. AD: Aalbersberg, op. cit. in note 23, 9 .
} 


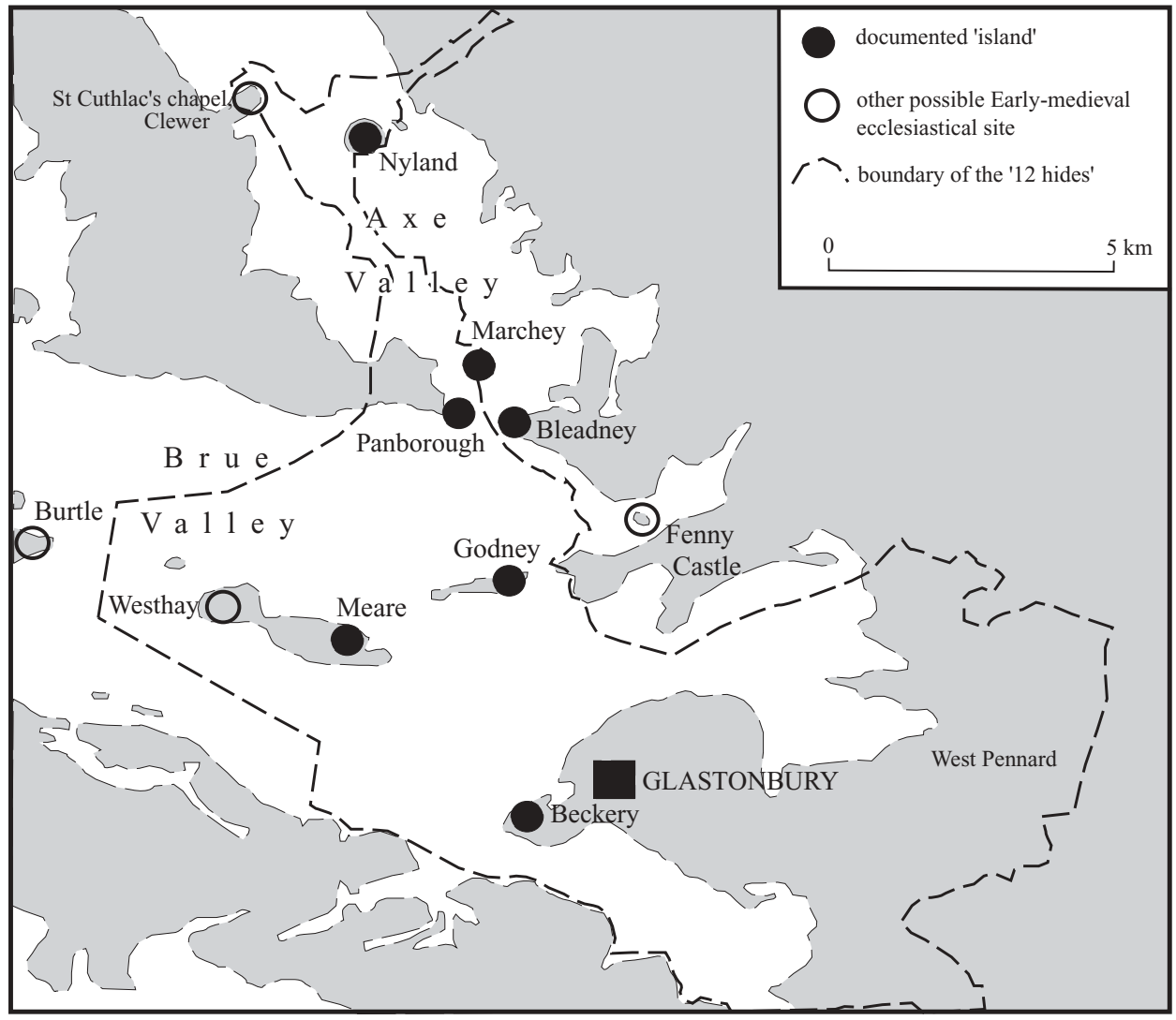

FIG. 4

The 'Glastonbury Twelve Hides' boundary, with the 'islands', and other places mentioned in the text (after Morland I 984, op. cit. in note 33, but including St Cuthlac's chapel on the Clewer promontory following Hazel Hudson, pers. comm.).

desiccation these peats would probably have been more extensive. The most recent deposits are freshwater alluviums, giving rise to soils of the Midelney Series, derived from rivers flowing off the adjacent uplands, particularly the Brue and Sheppey that were diverted through Meare during the medieval period (see below). ${ }^{27}$ In the palaeochannel of the former Brue/Sheppey just south of the Panborough-Bleadney Gap (Fig. 3), the onset of this sedimentation is dated very approximately to A.D. I ooo..$^{28}$

\footnotetext{
27 Aalbersberg, op. cit. in note 23, 93; B. W. Avery, Soils of the Glastonbury District of Somerset (Sheet 296) (Harpenden, I 955), 6o-2; Findlay, op. cit. in note 24, I 22-3; Housley et al., op. cit. note 23, I 9 .

${ }_{28} \mathrm{I}_{53} \mathrm{I} \pm 35 \mathrm{BP}, 535^{-5} 59 \mathrm{cal}$. AD, a date from shell and which is therefore expected to be c. $400-500$ years too old (due to the carbonate material): Aalbersberg, op. cit. in note 23, 93.
} 


\section{ISLANDS IN THE MIST: THE EARLY HISTORY OF THE MEARE ESTATE AND SIGNIFICANCE OF THE 'GLASTONBURY TWELVE HIDES' (Fig. 4)}

Meare was amongst the earliest grants to Glastonbury Abbey in the late 7 th century, which might in itself reflect that these freshwater backfens were of some special significance. Several charters, of varying integrity, relate to Meare:

670/72: The earliest reference is possibly in a charter of c. 670 , surviving only as a later copy that Abrams regards as a forgery but probably with some authentic elements; Finberg also suggests it may have some authentic basis. ${ }^{29}$ It records a grant by King Cenwalh of Wessex to Abbot Beorhtwald (the first Anglo-Saxon Abbot of Glastonbury) of one cassatum at Ferramere [Ferlingmere, later Meare] with two small islands, woods and a fishery. ${ }^{30}$ This grant was confirmed in a spurious charter of 725 (see below).

680: An authentic charter of 68o records the grant by Haedde, bishop of the West Saxons (at Winchester) of three hides at Leigh (in Street, near Glastonbury) and two manentes at Meare [Meare and Westhay or Godney?] to Haemgils, Abbot of Glastonbury. ${ }^{31}$

725: The 'Great Privilege of King Ine': a spurious charter that purports to be a grant by King Ine to Glastonbury of various lands, including the island of Sowy south of the Poldens, and a confirmation of an earlier grant of land at Meare, Beckery, Godney, Marchey, and Nyland in $670 .^{32}$ This appears to be a Ioth-century creation, which was intended to support Glastonbury's claim to a number of its estates, including its series of island in the Levels.

956: Confirmation of the grant of a vineyard and land at Panborough to Glastonbury. ${ }^{33}$ The only charter with a boundary clause that indicates that while most of the peatlands north of Meare were unenclosed moor, there may have been some reclamation along the southern fringes of Wedmore Island.

By the early i 2 th century Meare lay within the 'Glaston Twelve Hides', an area around Glastonbury granted to the Abbey in a series of charters dated c. 670-85, 7 I2-I8 and 955-75, and which later enjoyed particular fiscal and jurisdictional privileges that were confirmed in by Henry I in I I 2 I and Henry III in I 2 I $7 .{ }^{34}$ The bounds of the Twelve Hides are described in c. I I 29, c. I 263 , c. I 342 , and in the early I6th century (Fig. 4). ${ }^{35}$ In Domesday the Twelve Hides are described as never having paid tax, and included 'an island called Meare', 'another island called Panborough', and 'a third island ... called Andersey' [Nyland Hill]. ${ }^{36}$ Other elements of what were to become part of the Twelve Hides have separate Domesday entries (e.g. Pennard), ${ }^{37}$ suggesting that the jurisdiction was still evolving in the late I Ith century. Although acquired in a piecemeal fashion, what became the Twelve Hides were essentially a dryland 'core' around

\footnotetext{
${ }^{29}$ S.227; Abrams, op. cit. note 5, I 24 and I69-7 I; H. P. R. Finberg, The Early Charters of Wessex (Leicester, I 964), No. 353

${ }^{30}$ G.C. II, No. 644; Malmesbury, Nos. 36, 42, 6o and 69; 7. Glaston., Nos. 16 and 42; Morland, op. cit. in note 7 , No. 29 .

${ }^{31}$ S. I $249 ;$ G.C. II, No. 639; Malmesbury, No. 36 .

32 S.250; G.C. I, No. i 99; Malmesbury, No. 42.

${ }_{33}$ S.626; G.C. II, No. 638; Malmesbury, No. 58; S. Morland, 'Glaston Twelve Hides', Proc. Somerset Archaeol. Nat. Hist. Soc., I 28 (1984), 37; idem, op. cit. in note 7, No. 43; H. Hudson and F. Neale, 'The Panborough Saxon Charter, AD956', Proc. Somerset Archaeol. Nat. Hist. Soc, i 27 (1983), 55-69. I wish to thank Hazel Hudson and Frances Neale for clarifying several issues regarding the boundary clause.

${ }_{34}$ Morland, op. cit. in note 33,35 ; Wells I, 3 I 3 ; G.C. I, No. 366.

${ }_{35}$ Morland, op. cit. in note 33 ; Malmesbury, No. 72; 7. Glaston., No. 3.

${ }_{36}$ G. Torn and F. Thorn, Domesday Book 8: Somerset (Chichester, I 980), 8, I [henceforward Somerset Domesday].

37 Somerset Domesday, 8, 2 I.
} 
TABLE I

HISTORIC LANDSGAPE GHARACTER TYPES IN MEARE PARISH, I806

\begin{tabular}{|c|c|c|c|c|c|c|c|}
\hline Source & Beckery & Bleadney & Godney & Marchey & Meare & Nyland & $\begin{array}{l}\text { Barrow } \\
\text { Hill, } \\
\text { Panborough }\end{array}$ \\
\hline $\begin{array}{l}\text { I: Malmesbury's } \\
\text { (No. } 36 \text { ) and John of } \\
\text { Glastonbury's (Nos. } \\
\text { I6, 42) account of } \\
\text { Cenwalh's grant of } \\
670 \text { (S.227). }\end{array}$ & yes & no & yes & yes & yes & yes & no \\
\hline $\begin{array}{l}\text { 2: Confirmation of } \\
\text { Ine dated } 725 \\
\text { (S.250; f. Glaston., } \\
\text { No. } 49 ; \text { Malmesbury, } \\
\text { No. } 42 \text { ). }\end{array}$ & yes & yes & yes & yes & yes & yes & no \\
\hline $\begin{array}{l}\text { 3: King Edgar's } \\
\text { confirmation of } 97 \mathrm{I} \\
\text { (S. } 782 ; \text { Malmesbury, } \\
\text { No. 60; 7. Glaston., } \\
\text { No. 7 I). }\end{array}$ & $\begin{array}{l}\text { yes, as } \\
\text { 'Little } \\
\text { Ireland' }\end{array}$ & no & yes & yes & yes & yes & yes \\
\hline $\begin{array}{l}\text { 4: Domesday }(D B \\
8, \mathrm{I}) \text {. }\end{array}$ & no & no & no & no & yes & yes & yes \\
\hline $\begin{array}{l}\text { 5: Henry I's } \\
\text { confirmation of the } \\
\text { Twelve Hides in } \\
\text { I I } 2 \text { I G.C. I, No. } \\
\text { 30 ; f f. Glaston., No. } \\
\text { 95). }\end{array}$ & yes & & yes & yes & yes & yes & yes \\
\hline $\begin{array}{l}\text { 6: Monington's } \\
\text { (c. I } 342 \text { ) list of } \\
\text { islands within the } \\
\text { Twelve Hides } \\
\text { (Monington, } 5 \mathrm{I} \text { ). }\end{array}$ & yes & no & yes & yes & $\begin{array}{l}\text { yes, as } \\
\text { 'Meare- } \\
\text { Westhay' }\end{array}$ & yes & yes \\
\hline $\begin{array}{l}\text { 7: Other references: } \\
\text { Sawyer I } 968 .\end{array}$ & & $\begin{array}{l}\text { charter of } \\
7 \text { I } 2 \text { (S. I 253); } \\
\text { Malmesbury } \\
\text { (Nos. 40,69) }\end{array}$ & & $\begin{array}{l}\text { charter } \\
\text { of } 7 \text { I } 2 \\
\text { (S. I 253) }\end{array}$ & $\begin{array}{l}\text { charter of } \\
680 \\
\text { (S. I 249) }\end{array}$ & $\begin{array}{l}\text { charter of } \\
959 \times 75 \\
(\text { S. I } 76 \text { I })\end{array}$ & $\begin{array}{l}\text { charter of } \\
956(\mathrm{~S} .626)\end{array}$ \\
\hline
\end{tabular}

Glastonbury itself (including West Pennard) and a large area of wetland in the Brue and Axe valleys. This suggests that the latter, of what must have been mostly unenclosed and undrained moors and waste in the pre-Conquest period, were somehow valued or viewed in a special way. The key features appear to have been five actual bedrock islands (Godney, Marchey, Meare, Nyland, and Barrow Hill by Panborough), along with two promontories referred to as 'islands' (Beckery and Bleadney), to which Glastonbury made special claim (Tab. I). ${ }^{38}$ Glastonbury's St

\footnotetext{
38 The charter of 7 I 2 refers to the Abbey's ownership of three hides on another promontory at Bleadney, which is also included in the spurious 'Great Privilege' of Ine of 725. It later appears to have been lost as it is included in a confirmation of Wells' possessions of $\mathrm{I}_{06} 5$ and does not appear in Domesday; it is only referred to in the early I 6 th-century version of the bounds of the Glastonbury Twelve Hides which may represent a late attempt to include yet another island/promontory in its special jurisdiction. Abrams, op. cit. in note $5,46-7 ; \mathrm{P}$. Rahtz and S. Hirst, Beckery Chapel, Glastonbury, I $967^{-8}$ (Glastonbury, I974), I I-I 2.
} 
Cuthlac's chapel in Clewer (see below) also probably lay on a bedrock promontory in the Axe Valley. ${ }^{39}$

The forgery of a charter by Cenwalh, a genuine charter of Edgar in $970,{ }^{40}$ and the appearance of the spurious confirmation by Ine in Malmesbury's Early History of Glastonbury, suggests that from the roth century, and increasingly in the I 2 th century, Glastonbury wished to establish the antiquity of its claim to these islands. The special significance of these islands is also reflected in the way that they are listed as being amongst the earliest grants to the Abbey. In the confirmation of Henry I, for example, the list of properties starts: 'the village of Glastonbury, in which the Old Church of the Mother of God is located . . . along with the church's islands - Beckery, which is called Little Ireland, Godney, Marchey, Meare, Panborough, and Nyland - shall be freer than the other properties . . .; only later are other, agriculturally more productive dryland estates listed including Street, Shapwick and Sowy. ${ }^{41}$ In the list of 'Principle places within the Twelve Hides' even Glastonbury is (erroneously) described as an island. ${ }^{42}$

The significance of these islands may be twofold. Firstly, they lay in an area of highly valued wetland resources, but which had ill-defined boundaries at a time when the increasing intensity with which the landscape was being exploited was liable to lead to disputes with other landowners. There may also have been a more spiritual significance, as most if not all the islands had associations with Christian sites. $^{43}$

- Glastonbury Tor may now be interpreted as an early monastic site, while nearby Beckery was occupied by a small monastic community associated with a cemetery (c. 7th-/8th-century?), being replaced by around the Ioth century with a simple stone chapel. William of Malmesbury and John of Glastonbury

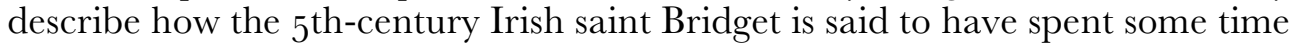
at Beckery. While this account may have been invented in order to create an illustrious history for the site, and provide a context for the Abbey having some relics of the early Irish saint, it forms part of the wider pattern of Glastonbury's islands having a special significance. ${ }^{44}$

- Of the various islands Meare soon acquired the most special status, reflected as its promotion, sometime between 97 I and i i 70, to one of the 'Seven Churches' which Glastonbury held and had exemption from Episcopal and other ecclesiastical jurisdiction (having been absent from the list of churches in Ine's 'Great Privilege' of 725, and Edgar's Privilege of 970). ${ }^{45}$ The other six — St John's Glastonbury, Street, Butleigh, Shapwick, Moorlinch and Middlezoy were all probably minsters for major estates, and the promotion of Meare to this 'premier division' of Glastonbury's churches may in part have been due to its

\footnotetext{
${ }^{39}$ I wish to thank Hazel Hudson and Frances Neale for raising this possibility.

${ }^{40}$ S. 782 ; Malmesbury, No. 6o; F. Glaston., No. 7 1.

41 f. Glaston., No. 95.

42 Malmesbury, No. 73.

${ }^{43}$ M. Aston, Monasteries in the Landscape (Stroud, 2000), 58, fig. 25; Rahtz and Hirst, op. cit. in note 38, I I-I 2.

${ }^{44}$ P. Rahtz, 'Pagan and Christian by the Severn Sea', 3-37 in Abrams and Carley (eds.), op. cit. in note 6; J. Crick, 'The marshalling of antiquity: Glastonbury's historical dossier', ibid., 2 I 7-43; Rahtz and Hirst, op. cit. in note 38,$37 ;$ Malmesbury, No. i 2; 7. Glaston., No. 28.

${ }^{45}$ Malmesbury, Nos. 42 and 6o; J. Carley, Glastonbury Abbey (London, I 988), 2 I-2 and 46.
} 
history: St Benignus, a disciple of St Patrick, is said to have established a hermitage at Meare during the late $5^{\text {th }}$ century, where he eventually died. Thurstan, the first Norman Abbot of Glastonbury, transferred the bones of St Benignus to the Abbey church in I og I, in what looks suspiciously like an attempt to bolster 'cult activity'. ${ }^{46}$

- Marchey is the 'small island' with a church referred to in a charter of 7 I 2, and which Malmesbury identifies as the chapel of St Martin. ${ }^{47}$ Marchey was a detached part of Meare parish until it was transferred to Wookey in the I th $^{\text {th }}$ century.

- In 676x685 and 705xi 2 Glastonbury was also granted land at Clewer on the west side of Wedmore Island. 'St Cuthlac's chapel' is mentioned in the early I6th-century bounds of the Twelve Hides, though not those of c. I 263 , and although Rahtz and Hirst suggest it was on Nyland Hill, Hazel Hudson has shown that Morland is correct in suggesting it was at Clewer. ${ }^{48}$

- Collinson mentions a chapel at Westhay 'long since ruinated', though there are no earlier references. ${ }^{49}$

- Malmesbury identifies Godney as having the chapel of the Holy Trinity. ${ }^{50}$

Several other islands within the Somerset Levels may also have had small preConquest monastic communities or hermitages with Glastonbury at their centre. East of Meare, at Burtle, a 'priory' existed in the I 3 th century at least, occupied by Brother Walter the hermit. ${ }^{51}$ This lay outside the Glaston Twelve Hides, but within Glastonbury's Pouholt estate. Fenny Castle, in Wookey parish, is a small bedrock island remodeled around the I 2 th century to create a motte and bailey castle, but quarrying during the igth century purportedly led to the discovery of 'upward of 20 ' inhumations, ${ }^{52}$ perhaps reminiscent of the cemetery at Beckery. Finally, the legend of St Indract describes his stay at 'Hwisc' that has been identified with Withy, a detached part of Shapwick parish on the coastal marshes of the Somerset Levels. ${ }^{53}$ A large oval enclosure at Withy is best interpreted as an early reclamation, and although there was no bedrock/dryland outcrop, this could also have had the appearance of an 'island'. ${ }^{54}$

46 7. Glaston., No. 86; Malmesbury 62, 86; Carley, op. cit. in note 7, xxxviii; idem, op. cit. in note 45, I 4 and Io6.

47 G.C. II, No. 640; Malmesbury, No. 73.

${ }^{48}$ S. I668 and S.I675; Malmesbury, Nos. 40 and 69; 7. Glaston., Nos. I6 and 47; Abrams, op. cit. in note 7, 90-2; Rahtz and Hirst, op. cit. in note 38 , I 2. There is probably no connection between this local saint Cuthlac and St Guthlac who was active in the Anglian region of eastern England. Hazel Hudson has shown that in Abbot Beere's perambulation in I5 Io there are too many landmarks between Nyland and St Cuthlac's chapel for it to be at Nyland. It lies across the Yeo and is associated with a place called 'Selysplace' which can be identified as a capital tenement in Clewer acquired in I 459 by John and Joan Sely (SRO DD/SS/bundle 6 no. 7); Morland, op. cit. in note 33,48 .

${ }^{49}$ J. Collinson, History of Somerset, 2 (Bath, I 797); Somerset SMR 23802.

50 Malmesbury, No. 73.

${ }^{51}$ G.C.I, I 62.

52 T. S. Holmes, The History of the Manor and Parish of Wookey (Bristol, I 886).

${ }^{53}$ Carley, op. cit. in note 45, I07-8; Costen, op. cit. in note 6, 50 and 55 .

54 S. Rippon, 'Infield and outfield: the early stages of marshland colonisation and the evolution of medieval field systems', 54-70 in T. Lane and J. Coles (eds.), Through Wet and Dry: Essays in Honour of David Hall (Sleaford, 2002). 


\section{THE MANOR OF MEARE AND ITS RESOURGES}

In the preceding discussion the islands and wetlands west of Meare, and the real or mythical early Christian associations ascribed to them, have been shown to have special symbolic significance to Glastonbury. Their role in promoting pilgrimage clearly had financial benefits, but the manor of Meare also contained a range of other more material resources that were of great value to the Abbey. Meare was a favoured residence of several abbots, and in contrast to bishop's palaces ${ }^{55}$ very few abbot's country houses have been recognized, let alone studied in detail. The example at Meare is particularly well preserved and well documented comprising a seigniorial complex that included a manor house, church, windmill, dovecot, orchards, vineyard and fishery. The adjacent planned village and openfield system occupied the dryland island, while the surrounding low-lying wetlands were utilized in a variety of ways: simply exploiting their rich natural resources, or improving the drainage in order to enhance their potential for agriculture.

THE SEIGNIORIAL GOMPLEX (Figs. 5-8)

The first detailed account of the manor of Meare is in Domesday:

An island called Meare is attached to this [Glastonbury] manor. 6o acres of land. Land for I plough, which is there. I o fishermen. 3 fisheries which pay $20 d$; meadow, 6 acres; woodland, 6 acres; vineyard, 2 arpents. I cob; I 3 cattle; 4 pigs. Value 20s; when the abbot acquired it, as much. ${ }^{56}$

The manor house (Fig. 5) was said to have been built by Abbot John Kent (129I-I303) and greatly improved by Abbot Sodbury (1322-35) through the construction of 'chambers . . . along with other sumptuous buildings' ${ }^{57}$ There must have been an earlier house as Abbot Michael Amesbury was granted the Abbey's 'country house' at Meare upon his retirement in I 252. ${ }^{58}$ The standing structure has been surveyed by the Somerset Vernacular Building Research Group. Jane Penoyre reports that the two-storey manor house has an L-shaped plan comprising a N.-S. main Hall range, with a large first-floor open hall, approached from the west by a former external staircase, and with tall arched and traceried windows, arched and moulded doorways, and a rare hooded fireplace all of the early I $4^{\text {th }}$ century. ${ }^{59}$ Only the roof has been replaced. The contemporary E.-W. south wing has a large first floor former chapel with seven arched windows (now blocked) and a doorway to the hall. Ground-floor accommodation in the two wings included a small hall, service rooms, and a former vaulted cellar, but with no evidence of a I 4 th-century kitchen that presumably lay in a detached block sited in the north-east corner of the courtyard. A porch was later added to the south side of the south wing and forms the entrance to the present farmhouse. Subsequent treering analysis of large oak floor beams suggest a felling date in the range of A.D.

\footnotetext{
55 Thompson, op. cit. in note I 8.

56 Somerset Domesday, 8, I.

57 7. Glaston., No. I 39.

58 H. Gray, 'Meare', Proc. Somerset Archaeol. Nat. Hist. Soc., 48 ( I go2), 4 I.

59 'A Survey and Report on Manor Farmhouse, Meare' by the Somerset Vernacular Building Research Group has been deposited in the Somerset Records Office, Taunton; and see Gray, op. cit. in note 58; A. Nesbitt, 'The manor house, Meare, Somerset', Archaeol. J., X ( I853), i 30-40; Phelps, op. cit. in note i 4, 57 I.
} 


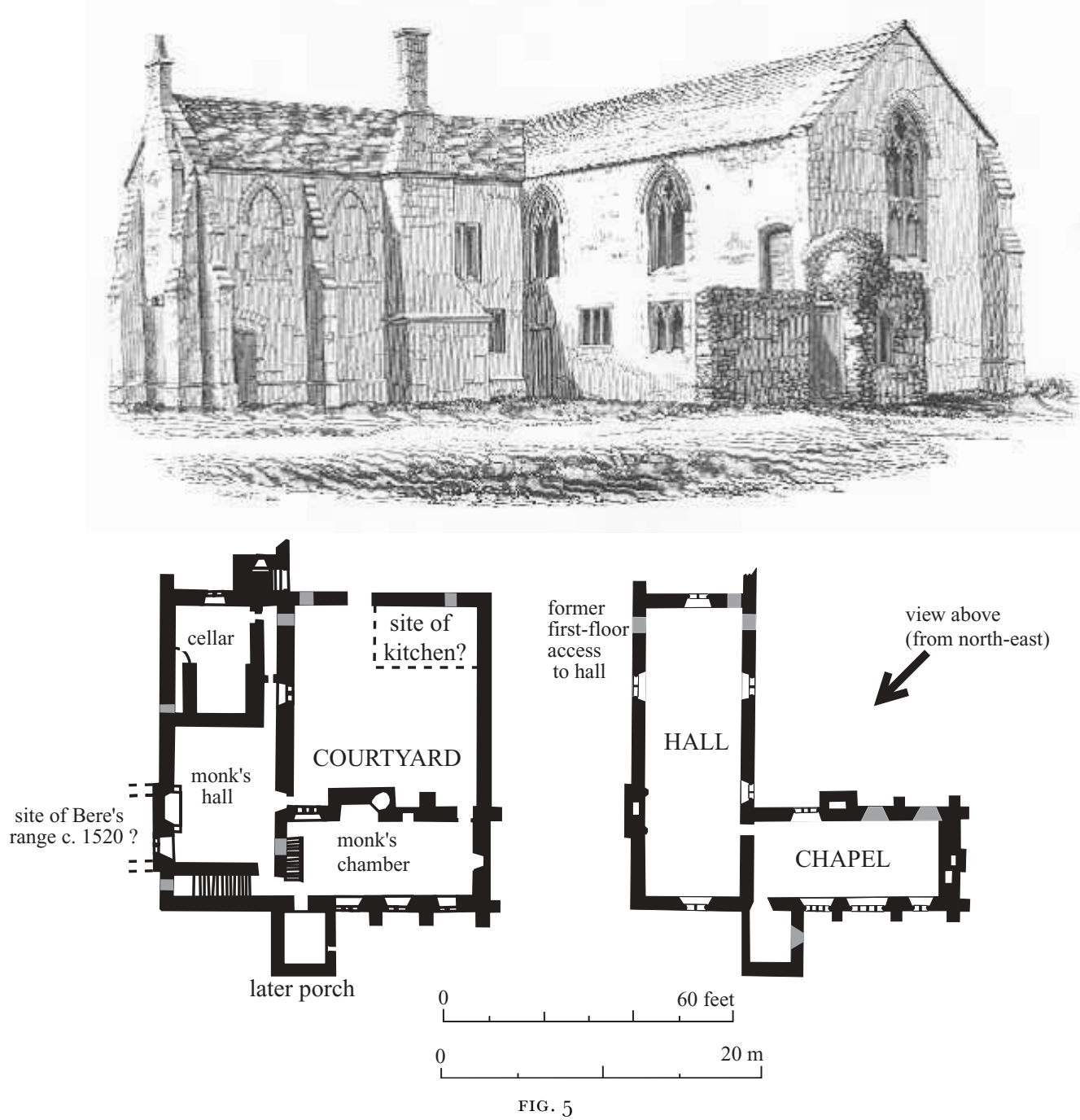

Engraving and plan (with additions) of the manor house c. I 860 (after Parker, in Nesbitt, op. cit. in note 59).

I 3 I 5-43 which is consistent with the construction being the work of Abbot Sodbury $(1322-35) \cdot{ }^{60}$ Evidence of former buildings on the west façade of the hall range may represent the additional accommodation that Abbot Beere is said to have constructed c. I 520 . The large size of the hall (I $4.8 \mathrm{~m}$ by 6.9 ) suggests considerable scope for hospitality, and with the main entrance originally on the west side, north of the probable site of Abbot Beere's range, it is possible that the

${ }^{60}$ M. Bridge, Tree Ring Analysis of Timbers from Meare manor Farmhouse, St Mary's Road, Meare, Somerset, unpubl., English Heritage Centre for Archaeology Rep., I03/2002. 


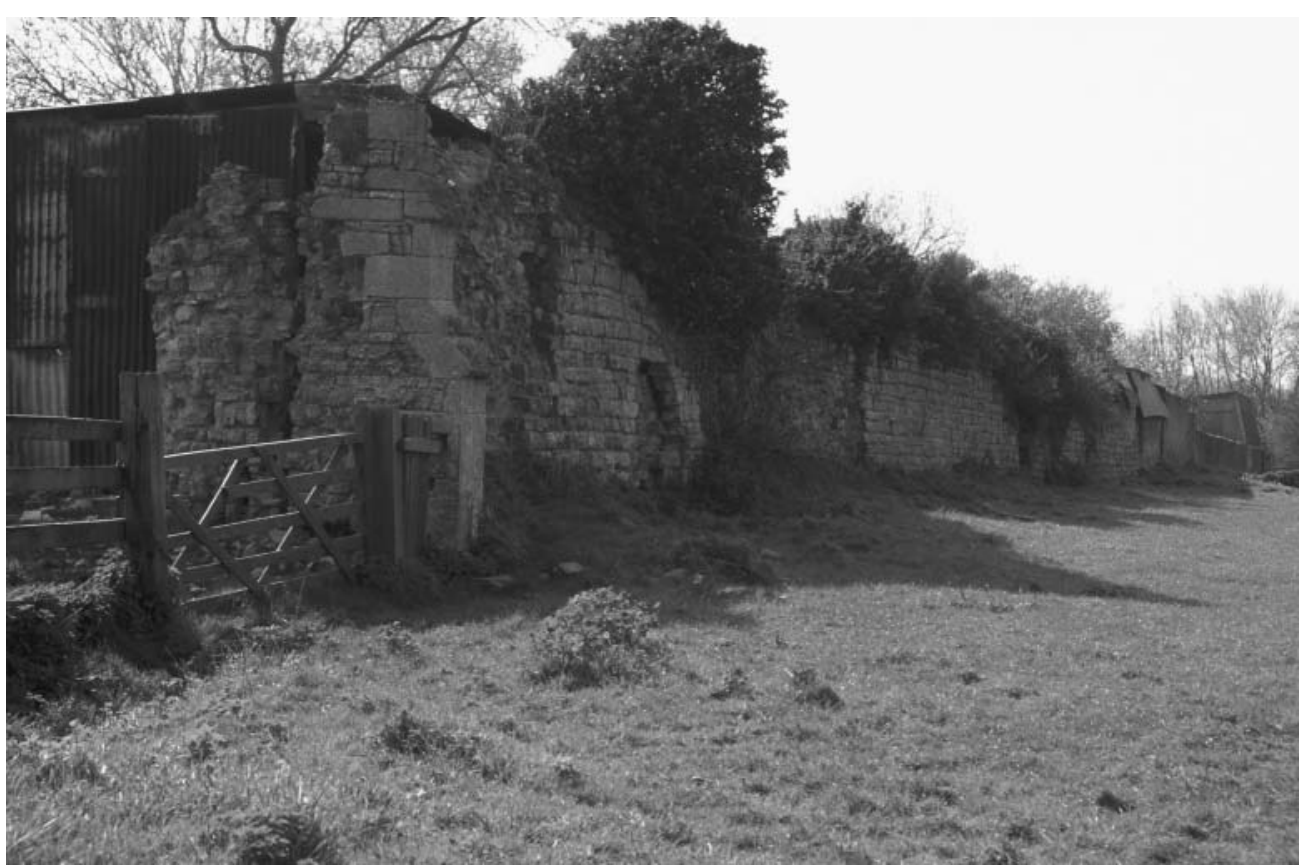

FIG. 6

The north-east corner of the manorial precinct wall. Photograph: the author.

primary access from Glastonbury was via the canalized river Brue to the north of the house, rather than road access to the south (see Fig. 8).

Abbot Sodbury is also said to have erected a windmill at Meare, ${ }^{61}$ which was probably located at the southern end of Millbatch Lane (Tithe Map field 398: 'Mill Close', Fig. I 2). A dovecot is recorded in I $260 .{ }^{62}$ Sodbury also enclosed the manorial complex with a wall, ${ }^{63}$ and in I 539 a survey of the possessions of the Abbey following the Dissolution states the precinct was 'walled to a great height ... of stone strongly encircled' containing 3 acres and I perch. To the north of the surviving manorial buildings, close to the line of the canalized Brue, this wall survives to a height of c. $3 \mathrm{~m}$ (Fig. 6). The vineyard recorded in Domesday and subsequent surveys was probably immediately to the east of manorial complex, in the field called 'Vineyard' in the Tithe Award (and within which the Fish House now lies).

The full text of the I 539 survey gives a detailed account of the manorial complex and its attached resources: 64

The site of the said manor is of ancient build, having a large hall, the one half whereof is covered with lead, and the other with slate; with eight chambers, a proper chapel, with a kitchen, buttery, and pantry, and all other houses of office very necessary. Finally, the house is

\footnotetext{
${ }^{61}$ 7. Glaston., No. I 39, recorded again in I 343/4: SRO T/PH/Lon Reel 9.

62 Ford, 203

${ }_{63}$ Gray, op. cit. in note 58; Nesbitt, op. cit. in note 59, I34; Phelps, op. cit. in note I 4, 570 and 574

${ }^{64}$ Pollard and Moyle, in Phelps, op. cit. in note I 4.
} 
fit for a man of worship, but the air thereof is not very wholesome, saving to such as have continued long therein; whereunto are appertaining three orchards, well replenished with fruitful trees; with three large ponds in them contained, full of all manner of fish which is here not put in value, until the King's Highness' pleasure therein be known. ... Also there is appertaining unto the said manor one fishing, called the Mere, which is in circuit five miles, and one mile and an half broad, wherein are great abundance of pikes, tenches, roaches, and eels, and of divers other kinds of to ferme xxvi $l$. xiii $s$. iii $d$.

Reference is also made to a 16 -year-old wood of 5 acres at Styveley [Stileway] and a Io-year-old 4-acre wood at Westhay; the game of swans, herons and pheasants; 30 able men 'ready to serve the King', and I 5 bondmen. In the manor of Godney there were four woods called 'Brode Oke-Common', 'Godley-Moore Common', 'Blackwars Wood' and 'Heath-Moor Common', along with the common of Godley Moor, 23 'able men to serve the King', and I bondman.

John of Glastonbury states that the chapel at Meare was built by Abbot Sodbury, who in I 323 petitioned Bishop Drokensford for its dedication to St Benignus. ${ }^{65}$ Presumably this replaced an earlier structure that held the bones of St Begninus before they were moved to Glastonbury in I og I (see above), and which is recorded in the reign of Henry II ( I I 54-89). ${ }^{66}$ The present chancel and tower date to the early i $4^{\text {th }}$ century, and may have been the work of Abbot Sodbury (I322-35), while nave is late I5th-century, having been rebuilt with finance provided by Abbot Selwood, whose initials appear on the parapet of the south aisle (Fig. 7). ${ }^{67}$

\section{THE DRYLAND ISLAND: PLANNED LANDSGAPE (Fig. 8)}

The nucleus of Meare village lies immediately west of the church/manor complex and comprises a series of tenement plots each with a 'toft'-like compound containing buildings at their southern end, fronting on to the former edge of the main street (before the enclosure of the roadside waste), with a 'croft'-like enclosure extended northwards down to the Brue. To the south of this block of tenements the road has a pronounced bulge, which may mark the site of a market place that by I 806 was infilled with cottages (cf. Figs. 8 and gA). These tenement-plots may have been laid out at the same time as, or imposed upon the strips of, a pre-existing open field. Their rather sinuous boundaries make it difficult to establish whether there was ever any uniform width to them, though close to the street-frontage plots in the central block (Nos. I 4, I 9, 22, 24, 29, 43, 4 I /2, 53 and 56) vary in width from I I 5 to I $30 \mathrm{ft}[35 . \mathrm{I}-39.6 \mathrm{~m}]$. Plot No. 9 clearly encroaches upon the cemetery and like the equally narrow plot io (c. $90 \mathrm{ft}[27.4 \mathrm{~m}])$ may be a later addition. The tenement blocks at the western end are appreciably broader than the others (Nos. 6r: i $60 \mathrm{ft}$ [48.8 m] and 65/68: $265 \mathrm{ft}[80.8 \mathrm{~m}])$. The buildings by the street frontage of Plot $6 \mathrm{I}$, however, only occupy the easternmost $\mathrm{i} 20 \mathrm{ft}[36.6 \mathrm{~m}]$ of this 'toft', with the remaining $40 \mathrm{ft}$ [ $\mathrm{I} 2.2 \mathrm{~m}$ ] appearing to have been added later. It would appear, therefore, that plot I 4 marks the original eastern limit of the tenement block, with

\footnotetext{
65 7. Glaston., No. I 39; Gray i 9o2, op. cit. in note 58; Phelps, op. cit. note I 4, 574 .

66 Wells I, 26; G.C. I, No. I; Wells I, I67.

${ }_{67}$ Carley, op. cit. in note 45, 62; R. Dunning, Somerset Monasteries (Stroud, 200 I), I I6; Gray, op. cit. in note 58; Nesbitt, op. cit. in note 59, I 34 .
} 


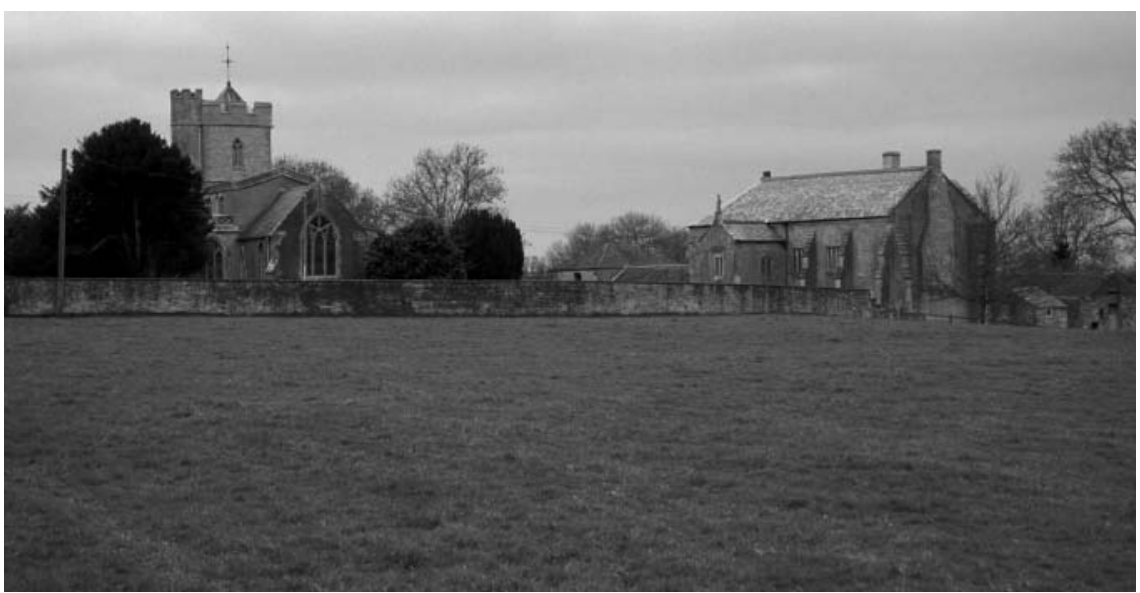

FIG. 7

The church/manor complex from the south-east. Photograph: the author.
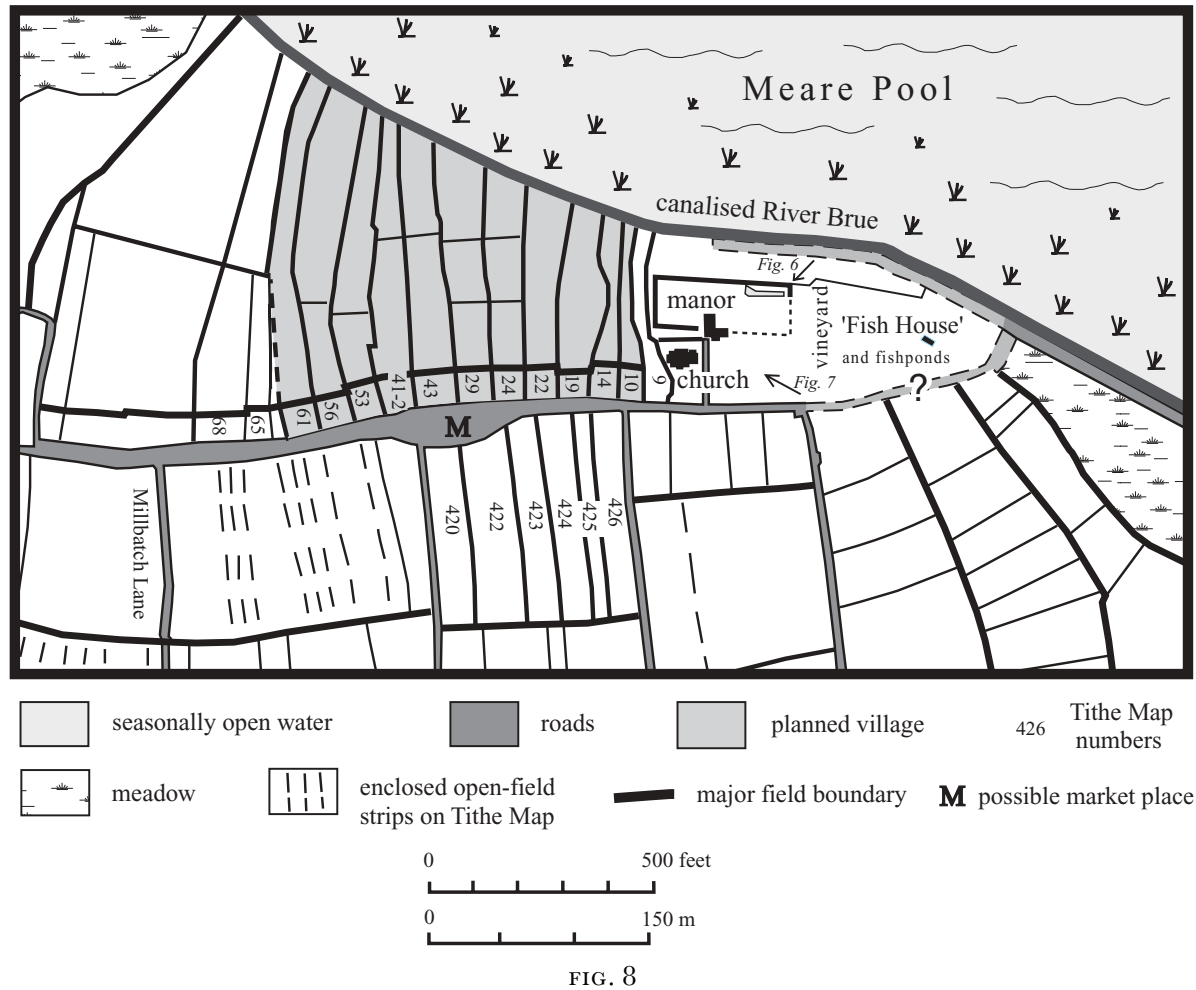

Plan of Meare village, based on the Tithe Map, with manor/church complex, location of the vineyard (based on the Tithe Map field-name), tenements plots (Tithe field numbers $9-68$ ) of planned village, possible market place and possible tenement plots (Tithe field numbers 420-6) to the south, amongst the surviving traces of the open fields. In this figure the road to Glastonbury is shown in its probable medieval position along the banks of the Brue. 


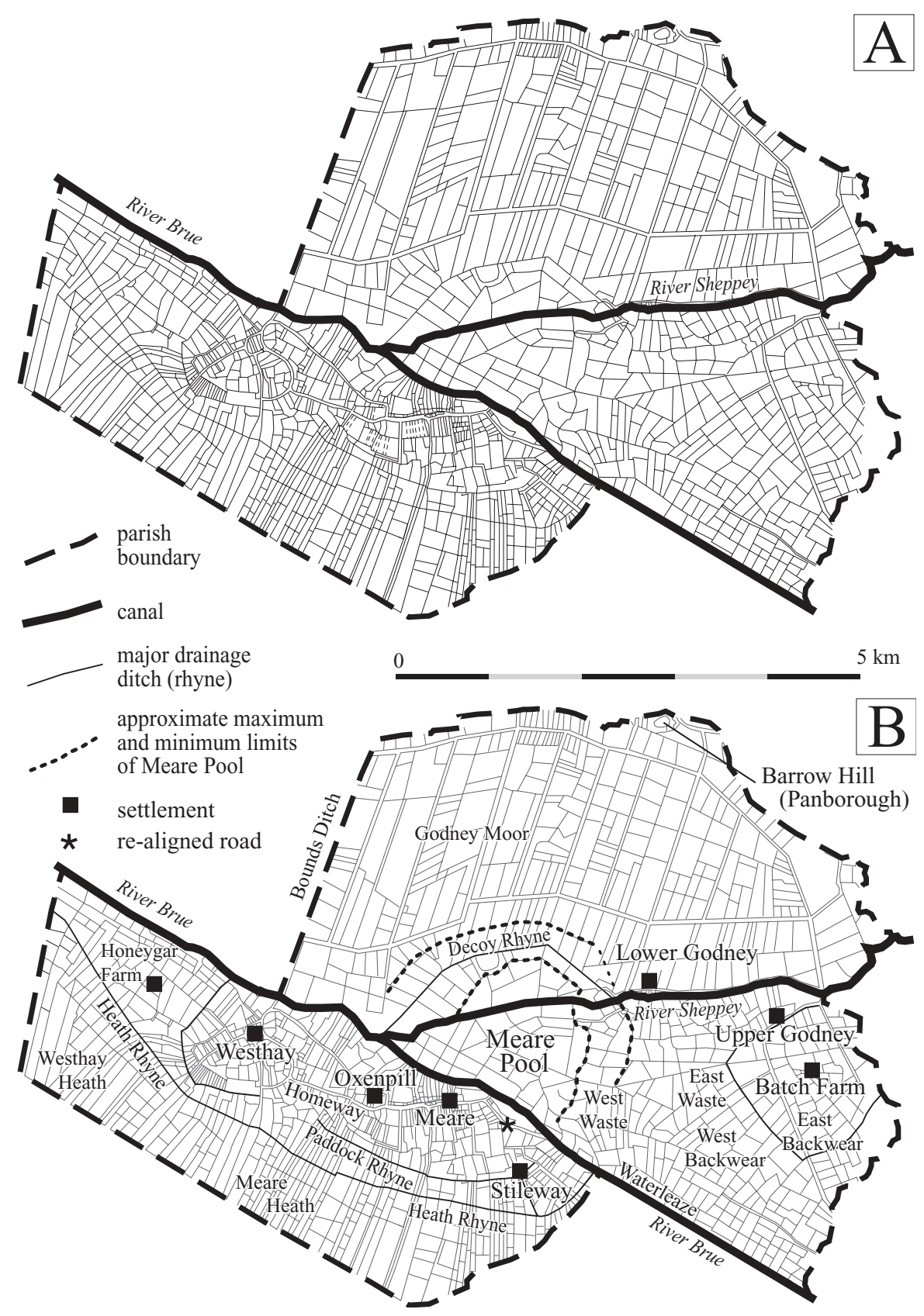

FIG. 9

The historic landscape of Meare as shown on the Brue Valley Drainage map, I 806 (Somerset Records Office Q/Rde I 2 I).

(A) Field boundaries and the two major canalized rivers. (B) Selected major landscape elements (including the probable maximum (winter) and minimum (summer) extents of Meare Pool), settlements, and named heaths/moors. Note that the road between Meare and Glastonbury appears originally to have run along the southern bank of the canalized Brue, though the c. I km stretch immediately east of the Manor House was later diverted south, up on to the island and through the former open fields (cf. Fig. 8). 


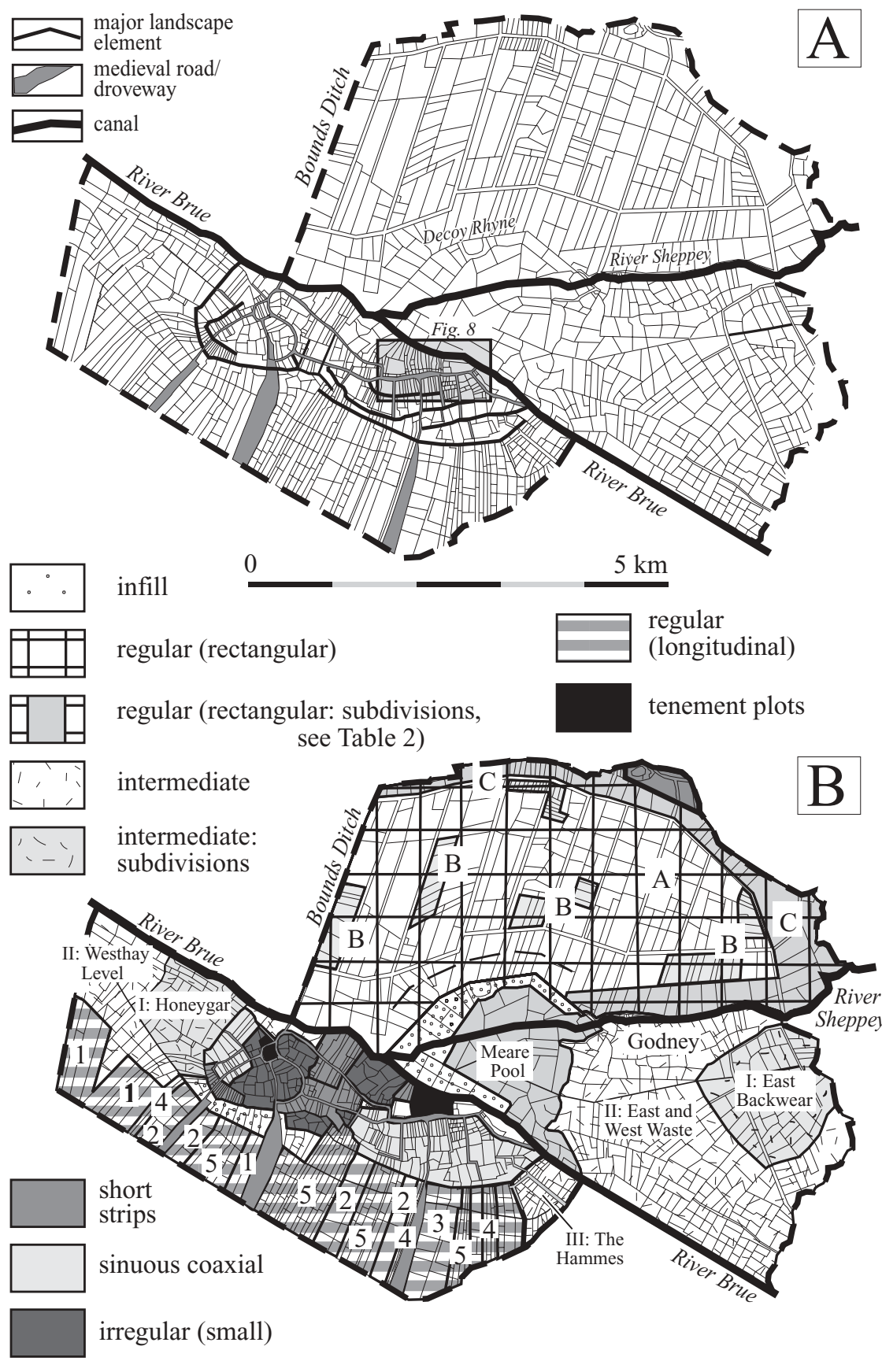

FIG. IO

Meare, historic landscape types, based on landscape in I 806. (A) Field boundaries in I 8o6, with key landscape features highlighted including furlong boundaries of the open-field system south of the planned village in Meare, and the series of droveways to the south across Meare and Westhay Heaths. (B) Historic landscape character-types and sub-types. See Table 2 for description. 


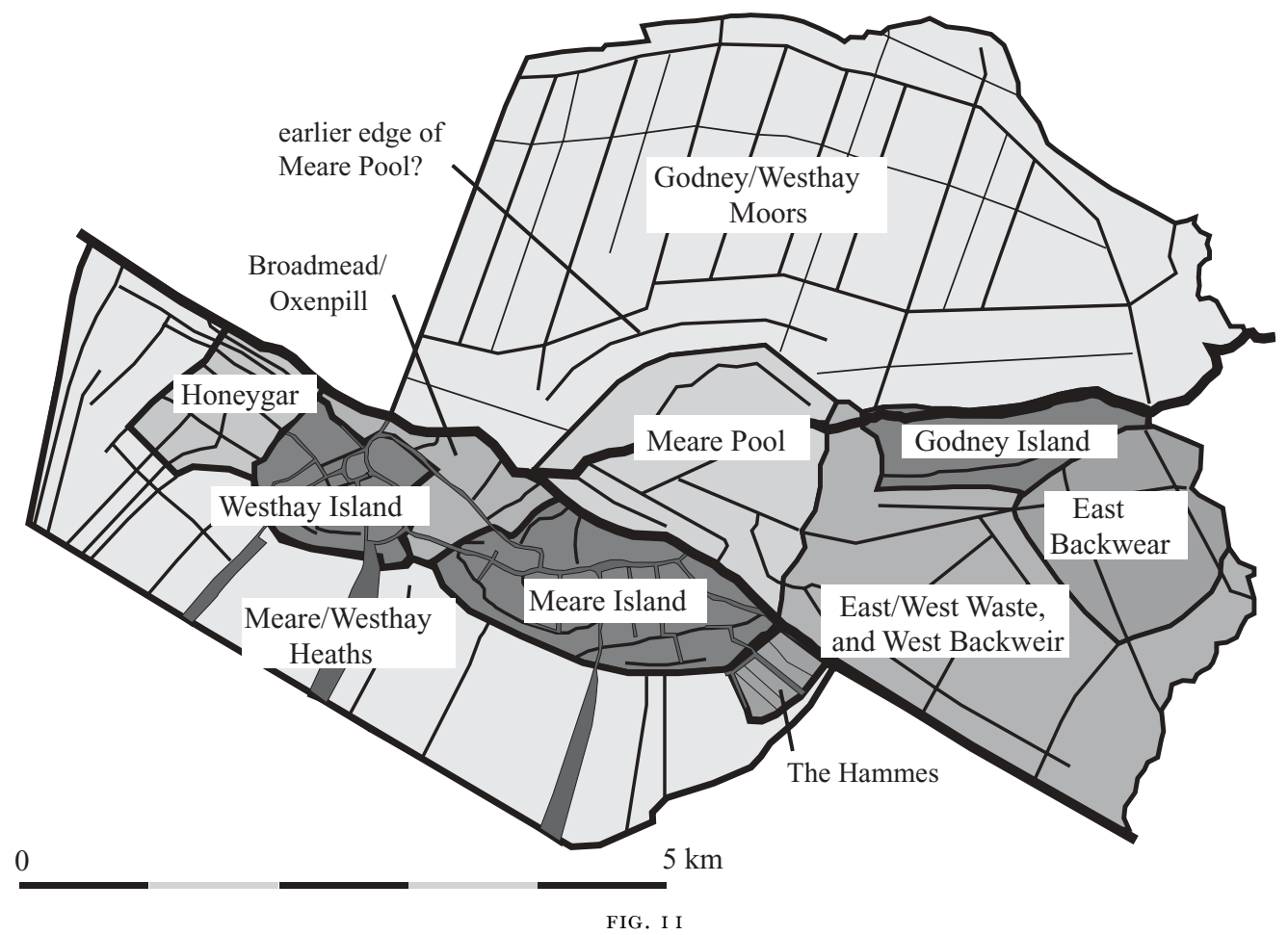

Meare, 'historic landscape character areas', and major landscape features, in i 8o6. See Table 3 for description.

plot 6 I marking the western limit, giving a total of ten plots c. I $20 \mathrm{ft}$ wide [36.6 m], with further tenements added to the east (Nos. 9 and io) and west (Nos. 65 and 68). Is it a coincidence that Domesday lists ten 'fishermen' in Meare?

South of Meare village, a series of roughly parallel E.-W. boundaries run the length of the island and form the skeleton of the medieval open-field system, parts of which were still unenclosed when Meare was first mapped in I 809 (Fig. 9). In the I 4 th century this was worked within a two-field system. ${ }^{68}$ The date when the open fields and nucleated village of Meare were created is unclear. Excavations within plot 68 revealed occupation from the late ioth or i ith century giving a terminus ante quem of that date for the initial block of tenements. ${ }^{69}$ Finds included small amounts of smithing slag, and a charred cereal assemblage dominated by wheat, along with some oats and peas/vetch. The weed seeds are mostly indicative of dry arable land, but some imply damp ground (water-plantain, hemp agrimony,

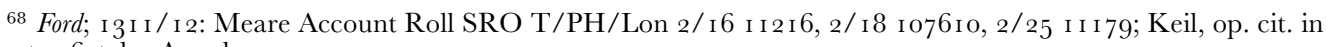
note $\mathrm{I} 6$, tabs. A and 4 .

${ }^{69}$ C. Hollinrake and N. Hollinrake, An Archaeological Evaluation at 'The Laurels', Meare Hospital, Meare, near Glastonbury (unpubl. rep, Somerset SMR PRN I5752, I993); C. J. M. Whitton and S. Reed, Archaeological Recording at 'The Laurels', 6oB St Mary's Road, Meare, Somerset (Exeter Archaeol. Rep. 02.52, (2002); Somerset SMR I5772).
} 
sedge, rush and bulrush), suggesting either that the cereals were in part grown on reclaimed land, or that the deposit also contained rush-based bedding material. ${ }^{70}$

The terminus ante quem of the late i oth/ I th century would place the date of Meare village alongside Shapwick, on the Polden Hills, as possibly being the creation of Abbot Dunstan (940-64). In the years leading up to his abbacy, Glastonbury was little more than an appendage to the royal demesne, whereas it is documented that Dunstan oversaw a spiritual revival, started rebuilding the church, and recovered and consolidated many lost lands. ${ }^{71}$ Palaeoenvironmental evidence also lends some support to the idea that the landscape in the Glastonbury area generally was being exploited more intensively at this time. A pollen-sequence from the moors north of Godney shows a marked decline in dryland trees and increase in clearance herbs around the I oth century, while about the same time there was increased sedimentation in the Sheppey palaeochannel suggesting an increase in arable cultivation within its catchment. ${ }^{72}$ This trend of increased intensity in the exploitation of the Glastonbury region can also be detected in the very top of a sequence from Meare Heath. ${ }^{73}$

DEALING WITH WATER: THE ENGLOSURE AND DRAINAGE OF THE WETLANDS

The low-lying areas around Meare island were amongst the most poorly drained parts of the Somerset Levels, yet even here Glastonbury embarked upon a programme of reclamation. Figure 9A shows Meare parish in i 806 (the earliest date for which we have a complete map), with key places referred to in the text highlighted (Fig. 9B). The different processes of enclosure and drainage gave rise to a series of major artificial watercourses (Fig. $9 \mathrm{~B}$ ), along with various patterns of fields, roads and settlements (Fig. Io), that taken together result in a series of landscapes of very different character. In Figure ioA several key components of the historic landscape are selected. The distinctive pattern of early droveways which can be identified in the later, post-enclosure, field-boundary pattern all radiate south towards Glastonbury's other manors on the Polden Hills and so suggest a link in the pastoral economies of the two areas (see below). Another key component of the historic landscape identified in Figure I $\mathrm{OA}$ is a series of artificial watercourses that run roughly perpendicular to the fen-edge. Those to the north of Meare Island represent the former edges of Meare Pool (see Figs. 9B and roB), while those to the south mark the edge of successive intakes from Meare Heath. An understanding of the process of reclamation achieved through historic landscape analysis allows a relative sequence to be suggested, while absolute dates by which certain areas had been reclaimed can be added through linking documentary references to the fabric of the historic landscape (Tab. 2).

Overall, the historic landscape can be broken down into a series of landscape 'types': blocks of landscape that possess certain common characteristics in terms of

\footnotetext{
${ }^{70} \mathrm{~J}$. Jones, Plant macrofossil assessment from the Laurels, Meare, Somerset, I 2- I 5 in Whitton and Reed, op. cit. in note 69 .

${ }_{71}$ Abrams, op. cit. in note 5, 7; Aston and Gerrard, op. cit. in note 6; Carley, op. cit. in note 45, Io; Stacey, op. cit. note i 6 , I I.

${ }_{72}$ Aalbersberg, op. cit. in note $23,57-64$ and 93

${ }^{73}$ Beckett and Hibbert, op. cit. in note 22, 594 .
} 
TABLE 2

HISTORIC LANDSGAPE CHARACTER AREAS IN MEARE PARISH, I 806

\begin{tabular}{l}
\hline I. Field boundary \\
pattern \\
\hline Irregular, large: large \\
fields of irregular, largely \\
polygonal, layout with little \\
or no sign of overall \\
planning. Incorporates the \\
meandering lines of former \\
natural streams.
\end{tabular}

Irregular, small: small fields of irregular, rectangular or polygonal shape with little or no sign of overall planning.

Sinuous coaxial: blocks of rectangular and longnarrow fields laid out between curving/sinuous axial boundaries.

Occasional dog-legs in field boundaries indicate former strip-fields.

Tenement plots: series of long narrow plots with subdivision at street frontage containing buildings.

Short strips: short, narrow, straight-sided strips laid out in small discrete blocks

2. Roads 3. Settlement 4. Soils $\begin{aligned} & \text { 5. Character } \\ & \text { areas }\end{aligned}$

6. Interpretation

absent absent

alluvium Meare Pool

Enclosure of last part of Meare Pool to be drained; $\mathrm{i}$ th century.

\section{sinuous, mostly spread} with areas along roads of roadside

waste

sinuous, restricted to
with areas road of roadside waste

$\begin{array}{ll}\text { sinuous, } & \text { in 'toft'-like } \\ \text { with areas } & \text { plots along } \\ \text { of } & \text { road } \\ \text { roadside } & \\ \text { waste } & \\ & \end{array}$

$$
\text { absent absent }
$$

fen-edge and alluvial margins

dryland
fen-edge
and
alluvial
margins

\section{Meare Island \\ Westhay Island}

Piecemeal enclosure; mostly post-Conquest

\author{
dryland Meare Island \\ Enclosure (late \\ medieval to I 9 th \\ century) of former \\ open-field furlongs \\ (laid out c. I oth- \\ century?).
}
Meare Island Planned village ?Westhay Island tenements; I oth century?

Westhay Island

Enclosed meadow; post-Conquest. Pattern of longnarrow fields suggest a former common meadow.

Intermediate: largely rectangular fields, with some indication of rudimentary structure, but no evidence for overall planning.

\begin{tabular}{|c|c|c|c|c|c|c|}
\hline \multirow[t]{2}{*}{$\begin{array}{l}\text { sub- } \\
\text { types } \\
\text { (see } \\
\text { Fig. I oB) }\end{array}$} & $\begin{array}{l}\text { I. small blocks of } \\
\text { rectilinear and } \\
\text { polygonal fields, } \\
\text { arranged around } \\
\text { a number of } \\
\text { straight axial } \\
\text { boundaries but } \\
\text { lacking overall } \\
\text { coherence. }\end{array}$ & $\begin{array}{l}\text { mostly } \\
\text { straight, } \\
\text { with little } \\
\text { roadside } \\
\text { waste }\end{array}$ & isolated farm & alluvium & $\begin{array}{l}\text { East Backwear, } \\
\text { Honeygar Farm }\end{array}$ & $\begin{array}{l}\text { Areas of High-/ } \\
\text { Late-medieval } \\
\text { reclamation. Pattern } \\
\text { of fields suggests a } \\
\text { landscape held in } \\
\text { severalty. }\end{array}$ \\
\hline & $\begin{array}{l}\text { II. blocks of } \\
\text { rectilinear fields, } \\
\text { arranged around } \\
\text { a number of } \\
\text { straight axial } \\
\text { boundaries } \\
\text { giving degree of }\end{array}$ & $\begin{array}{l}\text { Few, } \\
\text { straight, } \\
\text { without } \\
\text { roadside } \\
\text { waste }\end{array}$ & absent & $\begin{array}{l}\text { Mostly } \\
\text { alluvium } \\
\text { (some } \\
\text { peat on } \\
\text { Westhay } \\
\text { Level) }\end{array}$ & $\begin{array}{l}\text { East and West } \\
\text { Waste, and } \\
\text { West Backwear } \\
\text { Westhay Level } \\
\text { (west of } \\
\text { Honeygar } \\
\text { Farm) }\end{array}$ & $\begin{array}{l}\text { Areas of late- and/ } \\
\text { or post-medieval } \\
\text { reclamation. Pattern } \\
\text { of fields suggests a } \\
\text { landscape held in } \\
\text { severalty. }\end{array}$ \\
\hline
\end{tabular}




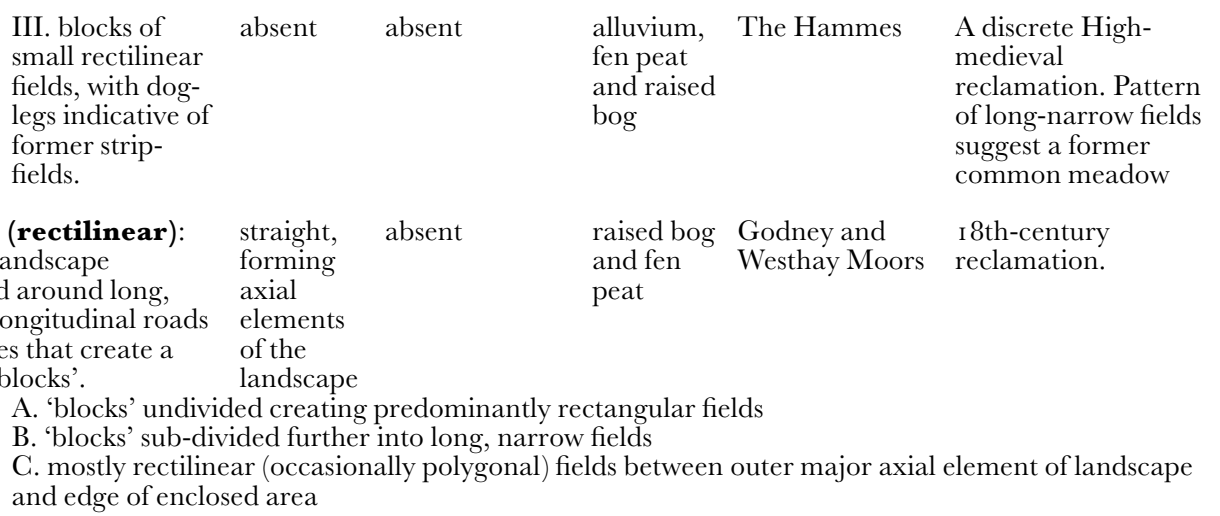

Regular (rectilinear): planned landscape structured around long, parallel, longitudinal roads and rhynes that create a series of 'blocks'. forming

axial

sub-

types B. 'blocks' sub-divided further into long, narrow fields

(see Fig. C. mostly rectilinear (occasionally polygonal) fields between outer major axial element of landscape $\mathrm{IOB}$ and edge of enclosed area

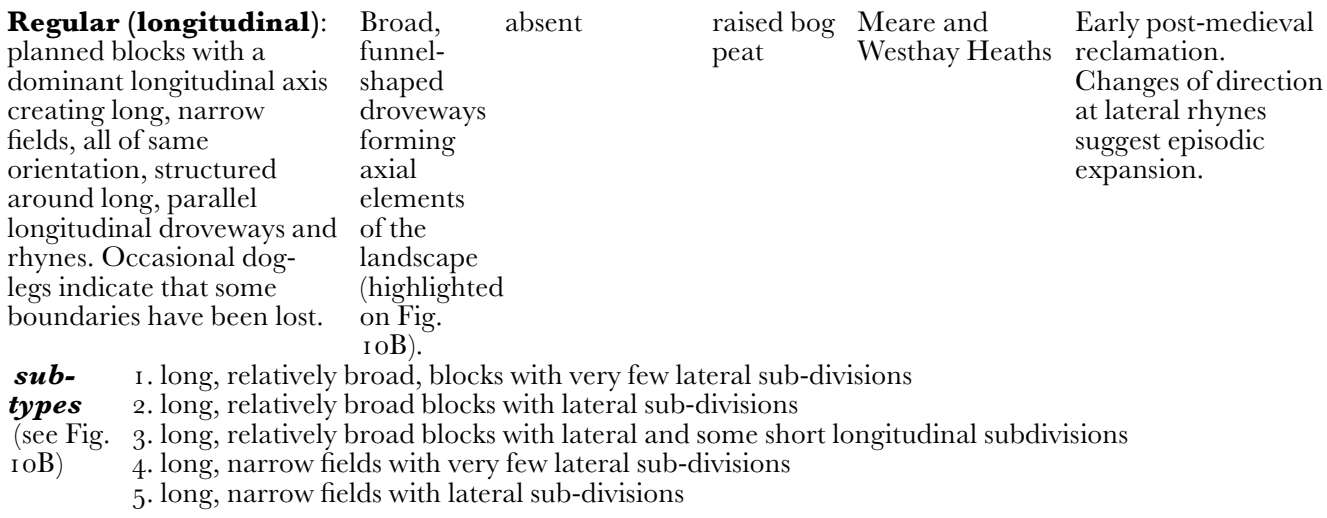

Infill: small plots filling the various various often fen- various Areas of reclamation space between major landscape features/other character areas. edge and locations wetland margins and enclosure; various dates.

their key defining features (Fig. IoB; Tab. 2, col. I-3). These generic historic landscape-types may occur only once, or in several separate locations (col. 5), but tend to be related to a specific topography/soil-type reflecting the significance of reclamation and water management in this particular set of circumstances (col. 4). This stage of the analysis is strongly morphological (of road and settlement patterns, as well as field-boundary patterns), but the results can then be simplified into fewer 'historic landscape character areas', which are discrete blocks of landscape, comprising one or more 'landscape-types', that form a coherent entity in terms of how they were created and functioned (Tab. 3, Fig. I I).

By linking this information on the creation and structure of the historic landscape, including field- and place-names, with references in the medieval written sources, the nature of the landscape can then be reconstructed at different points in time (Figs. I 2-I3). In I I 89, there was some meadow in Meare though its location is not evident. ${ }^{74}$ Later sources, however, do contain references to specific

${ }^{74}$ Sully, op. cit. in note 9, 28-9. 
TABLE 3

THE 'ISLANDS’ OF THE GLASTONBURY TWELVE HIDES

\begin{tabular}{lll}
\hline Character area & Landscape type(s) & soils \\
\hline Meare & $\begin{array}{l}\text { irregular, intermediate, sinuous } \\
\text { coaxial, short strips and } \\
\text { tenement plots }\end{array}$ & dryland and adjacent fen-edge
\end{tabular}

Complex landscape comprising a manorial complex within a walled precinct, adjacent church and planned village, open fields (sinuous coaxial type landscape), and some fen-edge reclamation. Three modern settlement foci (Fig. $9 \mathrm{~B})$ of which Meare village appears to comprise a discrete block of planned tenements, whereas Oxenpill consists of a later, lose agglomeration of farmsteads and cottages. In its present form Stileway is I gthcentury, though 'building land' is mentioned there in I 340 (Meare Court Roll: SRO T/PH/Lon 2/24 I 0773).

$\begin{array}{ll}\text { Westhay } & \text { irregular, intermediate, short dryland and adjacent fen-edge } \\ \text { strips and (?) tenement plots }\end{array}$

Complex landscape at western end of Meare Island, with a possible small block of planned tenements to southwest of Manor House Farm. Irregular fields on dryland, with area of fen-edge enclosures/reclamation (shortstrip type landscape) to south and west. No 'sinuous coaxial' type landscape suggestive of former open fields.
Godney Island$$
\text { irregular }
$$
dryland, fen-edge and adjacent alluvium

Area of mostly irregular landscape on and around the bedrock island (though only really evident on the ground, not the I 806 map). A long sinuous boundary runs west from Godney Farm along the watershed of the bedrock ridge. The modern hamlet (Lower Godney) lies on the alluvium next to the Sheppey, though historically the settlement focus may have lain on the bedrock/fen-edge at Upper Godney (Fig. 9B).
Meare Pool
intermediate, and infill
alluvium

Area of irregular character in the central/eastern area of the former Meare Pool, which post-date the canalized River Sheppey (now the James Weir River). Defined on the north/west by a sinuous boundary that may represent an earlier limit to its drainage/enclosure; the area between this boundary and Decoy Rhyne is one field wide and of 'infill'-type landscape (Fig. IoB). Intermittent field boundary to the north/west of, and concentric with, Decoy Pool Rhyne and which marked the limit of flooding on I 6 January I 947 might represent the original maximum limit of the Pool. The drainage and enclosure of Meare Pool appears to have started in the early i 7 th century (see below).

East Backwear intermediate

alluvium

Area of intermediate character, centred on Batch Farm, slightly more irregular in character than the to areas to the west and south, and bounded by a near continuous rhyne defining a sub-rectangular enclosure. In I 5 I 5 Beere Survey Estbackweare is described as arable in the West Field of Godney.
East and West Waste, and West intermediate
alluvium, fen peat

\section{Backwear}

Area of intermediate character showing greater regularity in the east (West Backwear) than the west (East and West Waste, and Waterleaze). The first mention of Waterleas (Waterleaze) was in the Beere Survey of I 5 I 5 when it was described as pasture. The phrase 'The bounds of Bacchyngwere' appears in I 35 I (Wells II, 6 I 7) though it is unclear whether any reclamation had occurred. In ${ }_{5}$ I 5 Westbackweare and Estbackweare (West and East Backwear to the south of Godney Hill), are described as arable in the West Field of Godney, which implies that quite a sizeable chunk of moor had been reclaimed.
Broadmead and Oxenpill
intermediate and irregular
alluvium

Area of irregular (Splotts) and intermediate (Broadmead and Westmead) landscape on the dryland between Meare and Westhay spreading on to the alluvium to the north, representing reclamation rooted on the fenedge. Homeway Road (between Meare and Westhay) cuts through these fields. Brodemede (Broadmead) and Oxenpull (modern Oxenpill) are first mentioned in the I 355 Monington Survey.
The Hammes (SE of Stileway)
intermediate
alluvium

Area of intermediate character on the alluvium east of Meare island, representing a discrete reclamation. Documented from Ford Survey of I 260 as Hammesmede.
Honeygar (Westhay Level)
intermediate
alluvium and peat

Area of intermediate character formed by a series of long axial boundaries parallel with the Brue. Williams, op. cit. in note 88, fig. I 2) shows this area as having been reclaimed c. I 400-I600 (though no evidence is given), but meadow and pasture at a place called Henangre or Henacre is documented from I 30 I / 2 (SRO T/PH/Lon 2/I4 
I I 272), presumably Hennigans (now Honeygar Farm). The frequency of references to Hennigans in early I 4 thcentury sources suggest that clarification of rights and dues was needed, perhaps because of active reclamation in the area between the islands of Westhay and Burtle. The field systems in the southern part of this area predate Heath Rhyne.

$\begin{array}{ll}\text { Meare and Westhay Heaths } & \begin{array}{l}\text { regular (longitudinal) with a raised bog peat } \\ \text { series of variants }\end{array}\end{array}$

Extensive planned landscape based upon closely spaced axial boundaries and long, narrow fields. These boundaries appear to have run initially between the fen-edge and Paddock Rhyne, then Heath Rhyne (as far as Honeygar), and were finally extended, sometimes with a slight change of direction (most obviously to the southwest of Westhay and south-east of Meare), from Heath Rhyne to the parish boundary. Some of these long narrow fields were not enclosed further, while others were sub-divided both laterally and longitudinally (Fig. $\mathrm{IoB}$ ). Williams (op. cit. in note 88, fig. I 2) shows this area as having been reclaimed in the period I $640-\mathrm{I} 770$, though no evidence is cited; in fact, references to meadow on the south side of Meare Island in I 355 (at Allen's Moor, Stileway, Southeth and Hethmor) may represent the first stage of this reclamation: Monington: BL Egerton 332 I). The Account Roll for I $343 / 4$ describes 'waste' at Hethmor 'south of Hamweye' [Hammes], 'outside the south part of Henangre' [Honeygar], and 'outside the south part of Halperryparroke' [Paddock Rhyne??].

Godney and Westhay Moors regular (rectilinear) with three raised bog and fen peat
variants

Extensive planned landscape based on a series of roughly N.-S. roads and rhynes, and two roughly E.-W. oriented roads laid out concentric with the northern parish boundary. The blocks they define are subdivided into a wide variety of rectangular fields, some of which are further subdivided into long, narrow plots; there is a less regular layout where the area between the outer-most axial roads and the parish boundary was enclosed (Fig. IoB). Enclosed I $78_{3}$ (SRO Q/RDe I 25).

meadows which were mostly on the alluvial fringes on the northern side of Meare island at Broadmead, Oxenpulle, the Hammes, and around Honeygar, but with limited intakes from the peat moors to the south such as Alenesmede (Fig. I2). Several former meadows were now used for arable at Orchardmede and Horchardmede implying an intensification in land-use (also seen at Sowy). ${ }^{75}$ Overall, it appears that by the mid-I $4^{\text {th }}$ century some $4^{-} 5 \mathrm{sq} \mathrm{km}$ had been reclaimed around Meare island. The use to which the peat moors was put is discussed below.

The survey of Abbot Beere in I5 5 suggests some significant changes had occurred in the Late-medieval Period. Some former meadows were used less intensively, such as Broadmead which was described as waste and heath, and $\mathrm{La}$ Done which was described as 'moor that was often underwater' (Fig. I3). In contrast, the areas east of Meare and south of Godney appear to have seen considerable reclamation by the early i6th century, notably at East and West Backwear and Waterlease. Overall, it would appear that around 9-I I sq $\mathrm{km}$ around Meare, Westhay and Godney were reclaimed by the early i 6 th century, with the greatest advances being made on the alluvial soils south of Godney. This was a period when Glastonbury had withdrawn from the direct management of its demesne, and it is likely that this near doubling of the reclaimed land was the work of tenants leasing large areas of demesne waste; little further progress is evident in the peatlands, which remained as common moors.

Later-medieval Meare, therefore, contained a number of landscapes, each with a very different physical fabric, resulting from very different patterns of landholding and processes of landscape creation. The dryland island has a landscape whose origin reflects the power of both lordship and community with a 

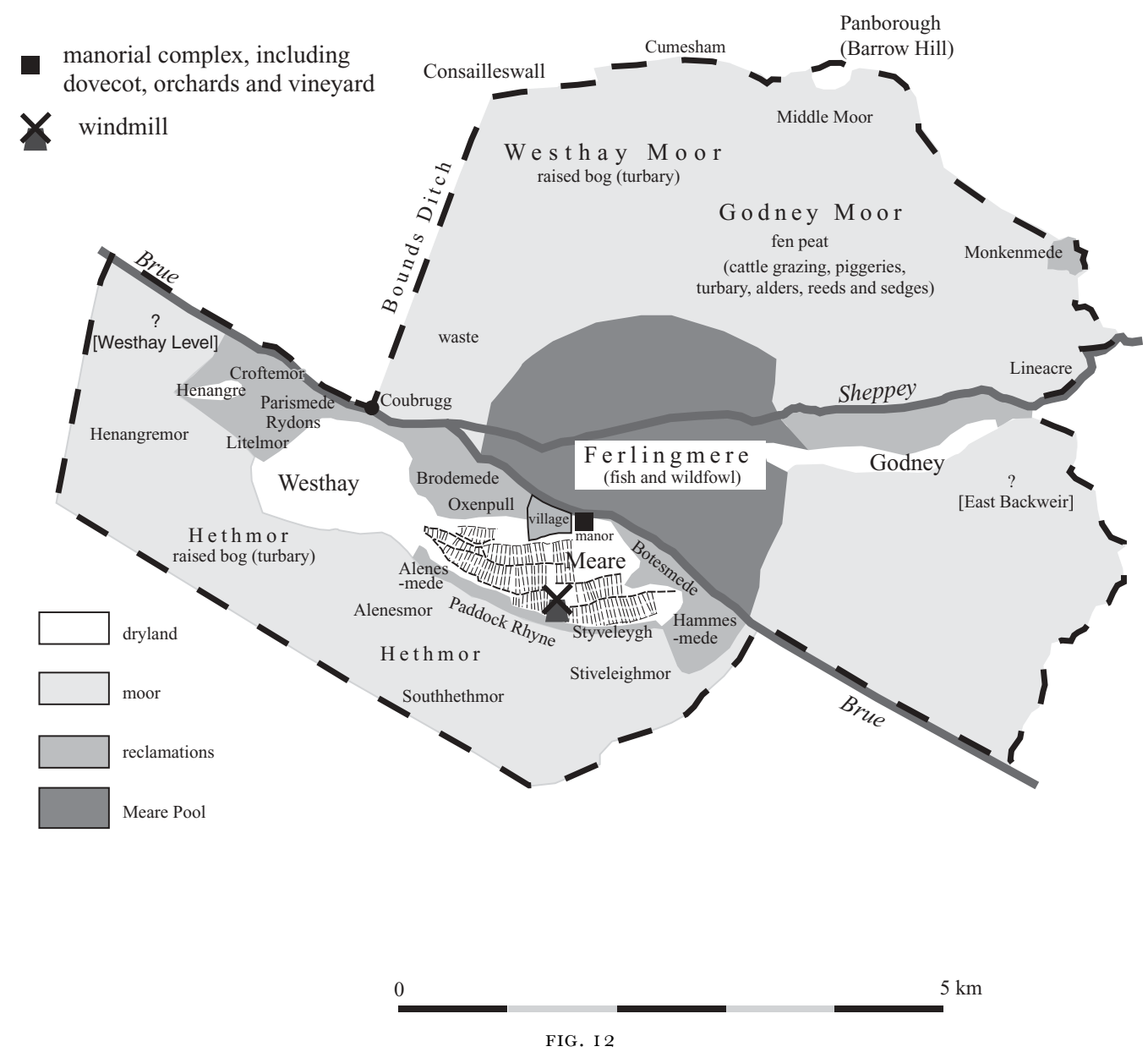

Meare c. I350 (excluding fish weirs: see Fig. I4) showing the major landscape elements and areas of land-use.

walled seigniorial (church/manor) complex, adjacent planned village, carefully laid-out and communally-regulated open fields, and small areas of reclaimed meadow extending a short distance from the fen-edge. By the I $4^{\text {th }}$ century reclamation had also started on the peat bogs south of Meare and Westhay, with a distinctive landscape of long, narrow fields that were extended in a series of stages, suggestive of a coordinated decision to enclose the heaths. This contrasts with the essentially Late-medieval landscape created in Backwear where the more irregularly arranged blocks of fields have the appearance of more gradual, piecemeal reclamation, and appear to have been held in severalty.

\section{The canalized rivers (Figs. $\mathrm{I}-3$ )}

Another important element of seigniorial intervention into the landscape around Meare was the canalization of several major rivers. Glastonbury was initially linked to the Bristol Channel via the river Brue, which originally flowed 

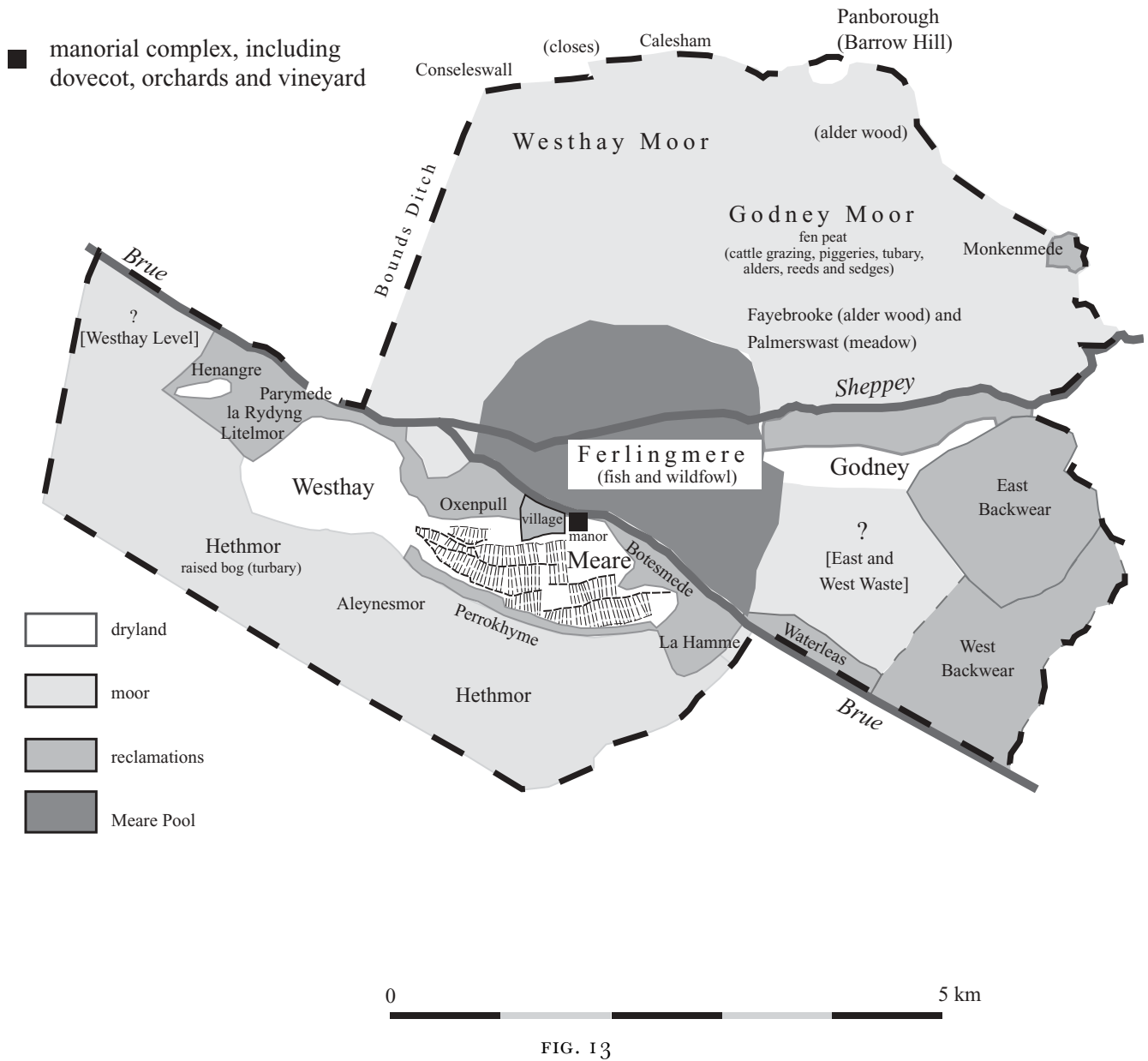

Meare c. I500 (excluding fish weirs: see Fig. I4) showing the major landscape elements and areas of land-use.

northwards through the Panborough-Bleadney Gap into the Axe Valley, past Cheddar, reaching the sea at Uphill (Fig. 2A); ${ }^{76}$ this river was later partly diverted and to avoid confusion is referred to here as the 'old Brue'. By the late i i th century, however, if not before an alternative route between Glastonbury and the Bristol Channel had been established, as the Brue was partially diverted via a major artificial watercourse that flowed past Meare to a point on Burtle Moor where it divided into two. One channel (the Old Yeo) went north to Mark (where it now changes its name to Pilrow) and then northwards to the small port and watermill at Rooksbridge on the Axe; another artificial watercourse (now called the Brue) went directly west to the Bristol Channel at Highbridge (Fig. 2B). John of Glastonbury's account of the carrying of St Benignus' bones from Meare to Glastonbury by boat

${ }^{76}$ S. Rippon, 'Waterways and water transport on reclaimed coastal marshlands: the Somerset Levels and beyond', in J. Blair (ed.), Water Transport and Management in Medieval England (Oxford, forthcoming). 
on a river in Iog I describes the Brue in its current (redirected and canalized) position, ${ }^{77}$ while this 'new Brue' west of Meare, past Burtle to Highbridge, is the subject of a list of drainage duties which appears to date to the later $\mathrm{I} 2$ th century. ${ }^{78}$ The Old Yeo (and so presumably Pilrow) is also probably referred to in this list of drainage duties, and certainly existed by I 235 when Robert Malerbe was said to be responsible for maintaining Glastonbury Abbey's waterways as far as Mark Bridge. ${ }^{79}$

Today, the 'new Brue' is the more important watercourse, but this may not have always been the case. Earthworks and the line of the Mark/Wedmore parish boundary suggest that the 'new Brue' originally swung northwards along the Old Yeo, and the mid-I6th-century bounds of Mudgley manor describes the 'Brue' as running from Meare to Mark. ${ }^{80}$ The topography of the Levels also suggests that the earliest course of the 'new Brue' is more likely to have flowed along Pilrow as this runs through the low ground west of the Isle of Wedmore (partly owned by Glastonbury), whereas the current Brue had to be cut through higher ground towards the coast (the property of other manors). Pilrow also joins the Axe at Glastonbury's port/landing place of Rooksbridge, ${ }^{81}$ whereas the 'new Brue' runs into what was probably a minor tidal creek at Highbridge where there is no evidence for a medieval port or landing place.

Glastonbury was also responsible for the canalization of other rivers and streams flowing into the eastern end of the Somerset Levels notably the Castellak (the modern Sheppey) which was diverted into the 'new Brue' (though some waters from the 'old Brue'/Sheppey system continued to flow northwards into the Axe Valley), ${ }^{82}$ and the Hartlake River which was also straightened and embanked in order to carry the waters of two upland streams (the Redlake and Whitelake) through the moors north of Glastonbury and into the 'new Brue' (Fig. 2 B). ${ }^{83}$

These artificial waterways served a number of functions. Water-levels within them were often higher than the ground through which they passed and so they cannot have played a part in the drainage of these areas, though by carrying freshwater across the low-lying moors they helped to prevent flooding from upstream. These channels were, however, primarily designed to improve Glastonbury's communications, and the Abbey's use of these canals is well documented. For example, Robert Malerbe was head boatman for the Abbey responsible for transporting wine from the vineyards at Panborough, Pilton and Meare, to Glastonbury. He also maintained the waterways between Clewer and Street Bridge

\footnotetext{
77 7. Glaston., No. 86; Wells $I, 226-8$.

${ }_{78}$ G.C. II, No. Iо I5; Wells I, 226-8; I would like to thank R. Dunning for improving upon the dating given in Rippon, op. cit. in note $3,2 \mathrm{I} 3$.

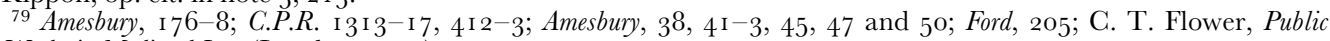
Works in Medieval Law (London, I 923), I 3 I.

${ }_{80}$ National Monuments Record CPE/UK I 924 3036; SRO DD/SAS PR 462.

${ }^{81}$ In I 500, for example, St John's church in Glastonbury used two boats to ship some seats from Bristol to Rooksbridge where they were transferred on to thirteen smaller vessels which sailed to Glastonbury via Meare: W. E. Daniel, 'The churchwardens' accounts of St. John's Glastonbury', Somerset Dorset Notes Queries, 4 (I895), $89-95$.

${ }_{82}$ G. Bradford, Proceedings of the Court of the Star Chamber in the Reign of Henry VII and Henry VIII (Som. Rec. Soc., XXVII, I9I I), 56-62; J. Hasler and B. Luker, The Parish of Wookey: A New History (Wookey, i 997), 30; G.C. I, No. i 6 I; G.C. II, No. 648; H. Hudson, New Wedmore Chronicles (Wedmore, 2002), 95-9.

${ }^{83}$ G.C.I, No., I 57; Wells I, 324; Wells II, 6 I 7.
} 
and between Mark Bridge and Glastonbury, and was coxswain of a boat with eight men used to convey the abbot to Meare, Brent, Butleigh, Nyland, Godney and Steanbow (near Pilton; Fig. I), together with all the abbot's men and kitchen, including the movable kitchen gear and cooks, and his huntsmen and hounds. ${ }^{84}$

\section{THE EXPLOITATION OF NATURAL WETLAND RESOURGES ON THE GLASTONBURY ESTATES}

MEARE POOL

The canalization of rivers is just one example of how Glastonbury manipulated water as a resource. Meare lay at the centre of a particularly ill-drained part of the Somerset Levels, and to the north of the island there was, until the I 7 th century, an extensive but fluctuating area of open water known as Ferlingmere (later Meare Pool). This lake was formed by water ponding-up behind the raised bog between Wedmore and the Polden Hills (Fig. 3), and coring has shown that it is filled with at least $2 \mathrm{~m}$ of detritus mud. ${ }^{85}$ The Beere Survey of I 5 I 5 described Meare Pool as being one mile long and three-quarters of a mile wide. The I 539 Survey described it as having a 'circuit five miles, and one mile and an half broad', while in the early I 540s Leland described Meare Pool thus:

... when the water is at its highest in the winter the Meare is four miles in circumference, and when at its lowest two and a half miles. The average is three miles. This lake or Meare is a good mile long, and at its western end it forms into a hollow for about a mile. Then the water divides into two arms, one flowing to Highbridge [the Brue] and the other to Rooksbridge [Pilrow] ${ }^{86}$

On the county maps of Saxton (I575) and Speed (I6ro) Meare Pool is still shown as a substantial body of water. ${ }^{87}$ The first serious attempt at its drainage was in the mid-I 7 th century, as in $1630 \mathrm{Mr}$ William Freake is described as having drained many hundreds of acres there; in 1638 there is reference to 480 acres of ground 'lately a fish pool', and in I 64 I tithes ceased to be paid on fishing, swans, fuel and turves in le Mere as 'the water was drained away'. ${ }^{88}$ In I 684 an enquiry into the tithes owed from the newly reclaimed land stated that 'New Cutts' (Decoy Rhyne: Fig. 9B) was dug some 25 years earlier. ${ }^{89}$

The extent of Meare Pool has never been properly mapped, but by relating the historical references given above to an interrogation of the historic landscape, its approximate extent can be established (Fig. 9B). The degree of seasonal fluctuation is described above, and this is likely to have varied from year to year, with the result that the most we can hope for is a mean summer extent (i.e. the permanent area of open water) and its mean winter extent. The southern limit to

\footnotetext{
${ }^{84}$ Amesbury, I 76-8; R. N. Grenville, 'Somerset drainage', Proc. Somerset Archaeol. Nat. Hist. Soc., LXXII (I 926), $\mathrm{I}-\mathrm{I} 3$.

85 Godwin, op. cit. in note 22.

${ }^{86}$ John Leland, Itinerary, ed. L. Toulmin Smith, The Itinerary of John Leland in or About the Years I535-1543, I (London, I 906), I $48-9$.

${ }_{87}$ W. Ravenhill, Christopher Saxton's I6th Century Maps of the Counties of England and Wales (Shrewsbury, I 992), 40-1; N. Nicholson, The Counties of Britain: A Tudor Atlas by Fohn Speed (London, I 995), I $5^{8-9}$.

${ }^{88}$ M. Williams, The Draining of the Somerset Levels (Cambridge, i 97o), го6; K. Harris, Glastonbury Abbey Records at Longleat House: A Summary List (Somerset Rec. Soc., 81, I 99 I), 87.

${ }^{89}$ Williams, op. cit. in note 88, 106.
} 
the Pool was clearly the embanked 'new Brue'. Three boundaries might mark the northern/western limit of the Pool: Decoy Rhyne and the roughly concentric fieldboundaries to the south and north (the latter also marked the limit of the flooding on I6 January I 947 as shown on RAF air photographs). ${ }^{90}$ The eastern limit of the Pool is less clear, though field boundaries continue the line of both Decoy Rhyne and its inner concentric alignment. These possible limits define areas that bear a close similarity to the extents described above: the smaller circuit has an area of c. 500 acres, remarkably similar to the area drained by William Freake, and is 0.8 miles $[\mathrm{I} .3 \mathrm{~km}]$ across with a circumference of 3.3 miles $[5.3 \mathrm{~km}]$. The Decoy Rhyne circuit is approximately I mile by I.3 miles [I.6 by $2 . \mathrm{I} \mathrm{km}$ ], with a circumference of 4.3 miles [6.9 km], while the largest circuit of boundaries gives a circumference of 3.2 miles [5. I km].

\section{F IS HING}

By Domesday, the Somerset Levels were the setting for the principal concentration of fisheries in south-western England. ${ }^{91}$ Most of the recorded fisheries in Somerset were on inland rivers, apart from Meare which was based upon Ferlingmere. The earliest reference to a fishery at Meare may be the charter of c. 670 though its authenticity is in doubt (see above). At Domesday, Meare had three fisheries which paid $20 d$ each, and ten fishermen are listed. The Sully Survey of I I 89 records two fisheries worth 3 od per year. $^{92}$

Meare was one of several manors appropriated by the Bishops of Wells during a long-running but ultimately unsuccessful attempt to absorb Glastonbury Abbey within the see, which was begun by Bishop Savaric (I I 9 I-I 205) and pursued by Bishop Jocelin ( I 206-42). ${ }^{93}$ In I 2 I 8 a commission was established to settle the resulting dispute, which assigned Meare, with eight other manors amounting to a quarter of the Abbey's possessions, to the bishopric. The Abbey retained the right to fish 'in the waters of Feringemere', perhaps reflecting the latter's value to the monastic community. ${ }^{94}$ Glastonbury successfully appealed with the result that it regained Meare and five other manors, and in I 252 the retiring Abbot Michael Amesbury was granted the manor as a country house, though the monks retained a warden of the fishery and moors. ${ }^{95}$ The rights to some of these fisheries were divided between different sections of the Abbey. In I i 93, for example, the abbot held one-third of the eels from the Street Bridge fishery, the rest being granted to the cellarer. ${ }^{96}$ A fishery at Godney was said in 1275 to have always belonged to the abbey's cook. ${ }^{97}$

\footnotetext{
${ }^{90}$ National Monuments Library GPE/UK, i 924, I 063.

${ }^{91}$ H. C. Darby, Domesday England (Cambridge, I 977), 279-86; R. Welledon Finn and P. Wheatley, 'Somerset', I 32-222 in H. C. Darby and R. Welldon Finn (eds.), The Domesday Geography of South-West England (Cambridge, I 967$)$.

${ }_{92}$ Sully, $28-9$.

${ }_{93}$ G.C.I, 5 , I $28 ;$ Wells I, 437 .

94 f. Glaston., No. i i o.

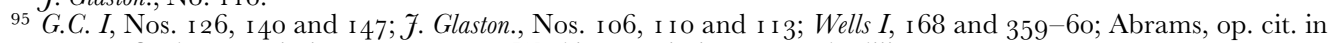
note 5 , I 2; Carley, op. cit. in note 45, 25-9; Watkin, op. cit. in note 7, xl-xliii.

96 G.C.III, No. I 30 I.

97 G.C. III, No. I 325 .
} 


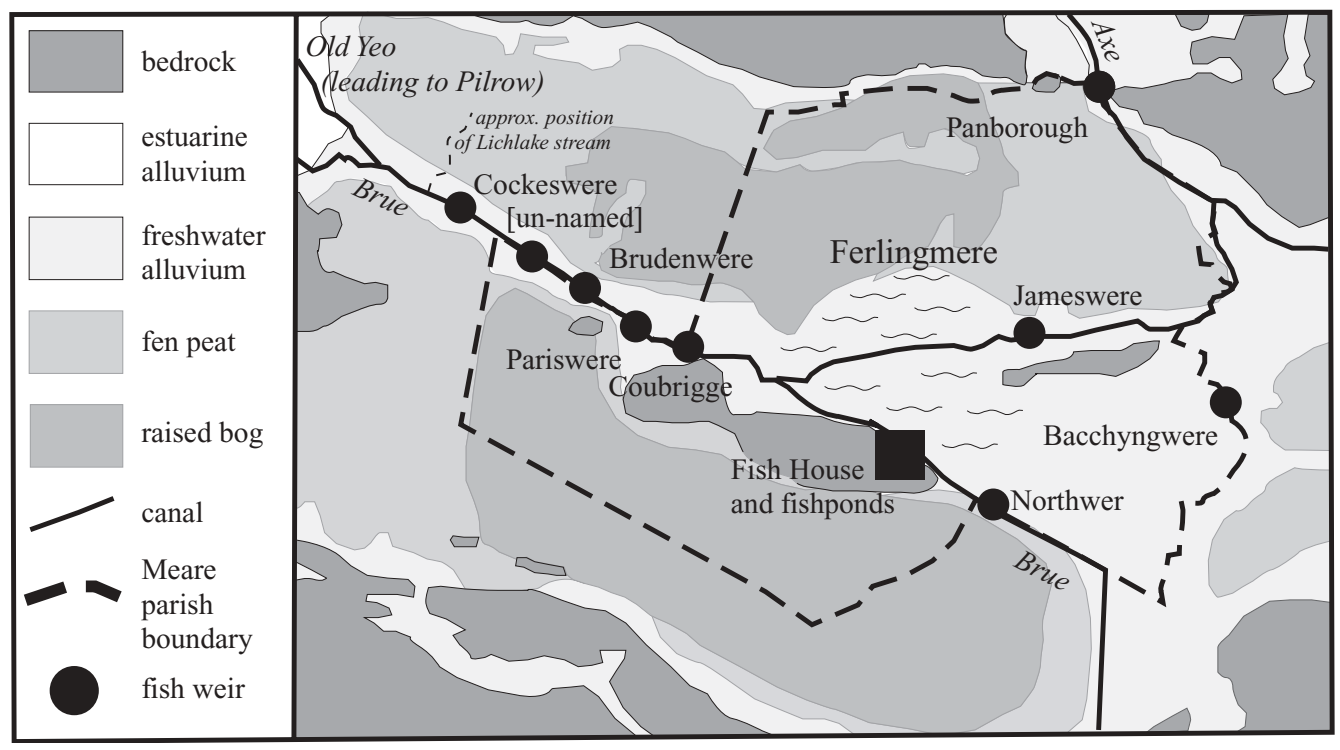

FIG. I 4

Meare Pool and the locatable documented fish weirs.

In I 260 one fishery at Meare was valued at i oos a year, along with fish weirs at 'Duchatswer' and 'Swire' worth I05s $8 d$ a year. ${ }^{98}$ The weir at 'Swire' is mentioned again in I $28 \mathrm{I} / 2$ and I $347 / 8$, and that meadow is also recorded there suggests it lay close to Meare Island, ${ }^{99}$ presumably on the Brue. A number of other fish weirs are also on the Brue (Fig. I 4). In I 327 , for example, an agreement was reached defining the boundary between the estates of the Abbey and the bishop which allowed the abbot access to the weirs of Hachwere and Bordenwere in Meare and Pariswere in Westhay, all on the dean's property; the abbot held the whole of the pool of Ferlyngmere with the rhyne or watercourse down to the dike of Lichelake [the 'new Brue'] and the whole right to fish there. ${ }^{100}$ In the early i 4 th century other weirs are recorded at Northwer by La Hamme, Coubrigge [Cowbridge] just to the north of Westhay, and Brudenwer to the west. ${ }^{101}$ Further weirs are recorded 'between Brudenwere and Lichelake to the west', while the I5 I5 Beere Survey mentions Cockeswere juxta Lichelake; Schorteswer is unlocated. ${ }^{102}$ More weirs lay on the old course of the Brue to the east of Godney, mentioned in an agreement between Ralph [of Shrewsbury] Bishop of Bath and Wells, and Walter [de Monington] Abbot of Glastonbury, settling a dispute over the bounds of Landscherleghe and

\footnotetext{
${ }^{98}$ Ford, 205.

99 Meare Account Roll: SRO T/PH/Lon 2/ I 4 I I 273 I; Meare Court Rolls: SRO T/PH/Lon 2/25 I I 79 ; I 340 Meare Court Roll: SRO T/PH/Lon 2/24 I07730.

${ }^{100}$ G.C. II, No. 647; Wells I, 226-8.

101 I 343/4 Meare Court Rolls: SRO T/PH/Lon 2/9 6365; I 3 I I / I 2 Meare Account Roll: SRO T/PH/Lon 2/ I 6 i I 2 i 6 . The i 558 perambulations of the bounds of the manor of Mudgley record 'Westheyes bridge sometimes called Cowe bridge' across the Brue immediately north of Westhay: SRO DD/SAS PR 462.

${ }_{102}$ I $343 / 4$ Meare Court Rolls: SRO T/PH/Lon 2/9 6365; i 3oo/i Meare Account Roll: SRP T/PH/Lon 2/ I 4 I 1272 .
} 
Bacchyngwere [Backwear], whereby both the Bishop and the Abbot were each allowed to make a weir there for catching fish. ${ }^{103}$ The I 5 I 5 Beere Survey mentions Fameswere whose name is reflected in the modern 'James Wear River' which takes the Sheppey across Meare Pool.

The nature of intertidal fisheries in the nearby Seven Estuary and Bristol Channel is now well known due to a number of archaeological surveys, ${ }^{104}$ though unfortunately there is less archaeological evidence for the nature of inland/riverine fisheries. Documentary sources, however, indicate the use of both large baskets ('puttes') and nets. In I 30 I / 2 there is reference to moor at Les Puttes juxta La Shirte, while in I359, for example, the Bishop of Wells was accused of making weirs "whenever they place "holies" [nets] and other instruments to catch fish there, by stopping up the water on the common ground of Thorlemore [Mark Moor] and More'. ${ }^{105}$ Abbot Beere's survey of Meare refers to a 'Botehaye' (boat yard?) to the east of the manor house.

\section{The Meare fish ponds and fish house (Fig. I 5)}

The Abbey's most important fishery was Meare Pool itself. The nearby 'Abbot's Fish House' is a two-storey stone building, I $2.4 \mathrm{~m}$ long by $6.6 \mathrm{~m}$ wide, which appears to have served partly a residential function on the two-celled upper floor, presumably accessed by a two-storey projecting room at the west end which was pulled down during the igth century, with the three-celled lower floor possibly used for preparing fish and storing tackle; there was no internal access between the floors. ${ }^{106}$ The present structure appears to date to the I 4 th century, and its style is the same as that of the manor house and church chancel, possibly all being the work of Abbot Sodbury (I 322-35). Though the Meare fish house is now a unique survival, others must have existed in and around the Somerset Levels. Wells, for example, held a fish house at Rodwere beside the Pilrow Cut, which in I 378 was the subject of repairs costing 40 s. $^{107}$

The survey of 539 refers to three fishponds (see above), which still survive today. ${ }^{108}$ The fishponds would have allowed fish to have been bred and stored, though it is not clear whether fish were preserved or supplied to the Abbey live. In order to keep fish fresh for the table, the kitchens at Glastonbury would have needed a system of tanks similar to those documented at Wookey in 'one close yard with water running through and walled about with 2 stone troughs to keep and

\footnotetext{
103 I35I: Wells II, 6 I 7 .

${ }^{104}$ S. Godbold and R. Turner, 'Medieval fish traps in the Severn Estuary', Medieval Archaeol., 38 (i 994), i 9-34; M. Hilditch, 'Preliminary survey of coastal archaeology including the intertidal zone between Wains Hill (Clevedon) and Sand Point (Worle), North Somerset', Archaeol. Severn Estuary, 8 ( 1 997), 99-1 02; R. McDonnell, 'Tidal fish weirs, west Somerset', Proc. Somerset Archaeol. Nat. Hist. Soc., I 23 ( I 980), 75-82; N. Nayling, 'Medieval and later fish weirs at Magor Pill, Gwent Levels: coastal change and technological development', Archaeol. Severn Estuary, Io (I 999), 93-I I 3; Rippon, op. cit. in note I, 220-5.

${ }_{105}$ Meare Account Roll: SRO T/PH/Lon 2/ I 4 I I 272 ; Flower, op. cit. in note 79, I 3 I-4.

106 Somerset SMR No. 23782; Gray, op. cit. in note 58; idem, 'The Abbot's Fish House, Meare', Proc. Somerset Archaeol. Nat. Hist. Soc., 72 (I926), xli; Nesbitt, op. cit. in note 59, I 34 and I 39 n.

${ }_{107}$ Wells I, 285 .

${ }^{108}$ Gray, op. cit. in note I 66, xli. These fishponds have previously been surveyed by Roger Leech: see M. Aston and E. Dennison, 'Fishponds in Somerset', $39 \mathrm{I}-408$ in M. Aston (ed.), Medieval Fish, Fisheries and Fishponds in England (Oxford, I988), fig. 3 .
} 


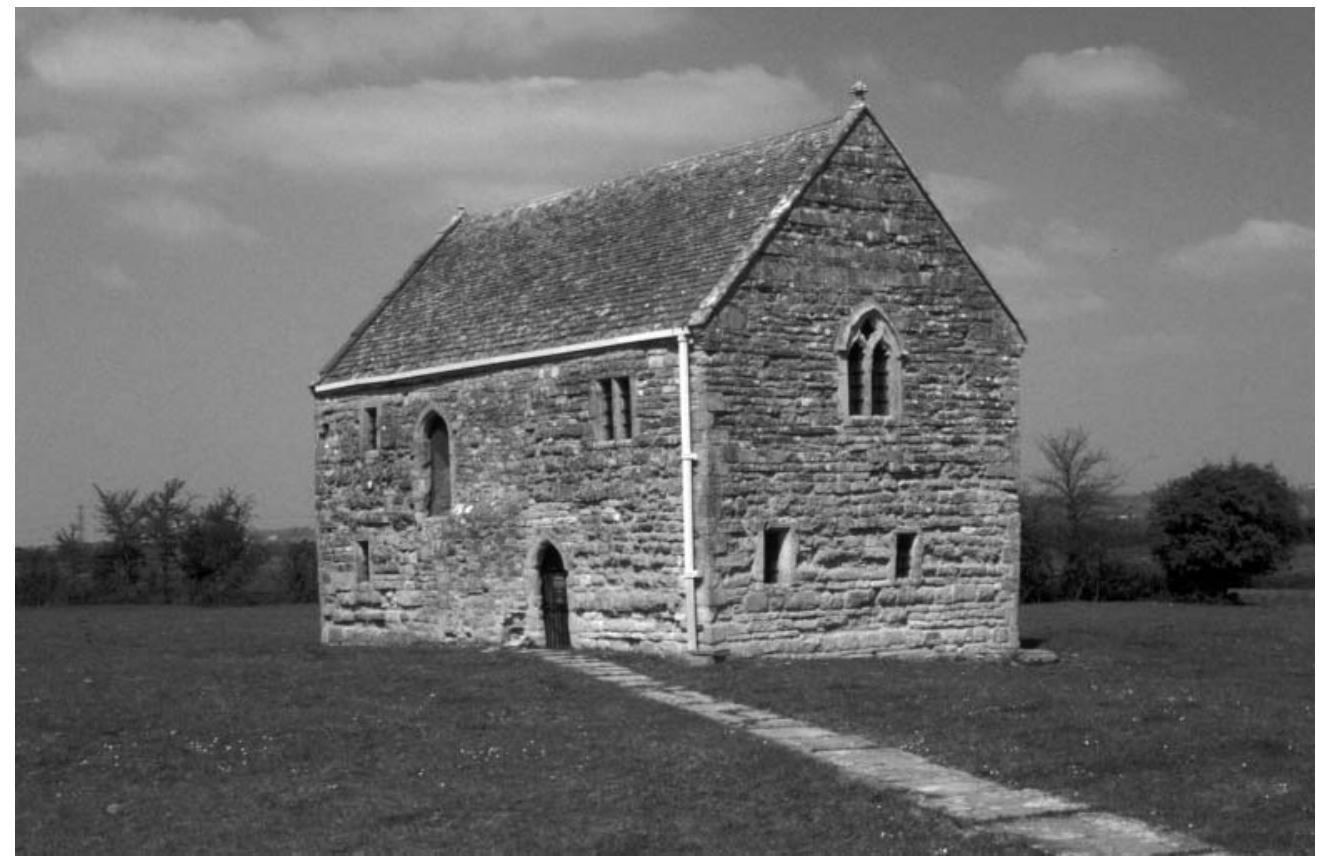

FIG. I 5

The Abbot's Fish House, from the south-west. Fishponds survive to the north, south and east. Photograph: the author.

water fish in'. Similar tanks have been excavated at Cumnor in Oxfordshire, a grange of Abingdon Abbey with its own fishponds as well as a set of stone tanks within its kitchen complex. ${ }^{109}$

\section{THE MOORS}

Meare island and the Meare Pool were surrounded by extensive areas of open unenclosed land known as the 'heaths' and 'moors'. ${ }^{110}$ The use of these unreclaimed areas is illuminated in a lengthy series of disputes between Wells and Glastonbury. John of Glastonbury criticized the Abbots of Glastonbury who 'in their negligence had for a long time not entered the north moor of Meare - that is from Lichelake as far as the moors of Godney, which are within Glastonbury's liberties - so that the monastery's right was to some extent forgotten'.111 In I 272 there were allegations of trespass on the Dean's manor of Mudgley and the Abbot's manor of

${ }^{109}$ J. Hasler, Wookey Manor and Parish I $544-{ }_{1} 84$ I (Somerset Rec. Soc., 83, I 995), 4; T. G. Allen et al., 'A medieval grange of Abbingdon Abbey at Dean Court Farm, Cumnor, Oxon', Oxoniensia, LIV (1994), 430-9.

110 E.g. Hethmor: i 343/4, Meare Account Roll, SRO T/PH/Lon Reel i; and see M. Costen, 'Abbot Beere's Terrier', 4 I-62 in M. Aston and M. Costen (eds.), The Shapwick Project: Third Report (Bristol, I 990); M. Ecclestone, 'Field names in the Shapwick court rolls', 2 I 3- I6 in M. Aston, T. Hall and C. Gerrard (eds.), The Shapwick Project: The Eighth Report (Bristol, I 998).

111 f. Glaston., No. I I 5; C. E. Chadwyke-Healey, Somersetshire Pleas, I (Somerset Rec. Soc., XI, I897), No. 572, L. Landon, Somersetshire Pleas, II (Somerset Rec. Soc., XXXVI, I923), Nos. I 37 and I 44. 
Meare. ${ }^{112}$ The dispute related to a 'moor called la Yelemore [modern Tadham, Westhay and Godney Moors] which extended from the dyke called Padenesbertheslak [Panborough stream] on the east by the water called Ferlingmere pool [Meare Pool] at the rhine down to the dike called the Lichelak [on Tadham Moor; Fig. 3] on the west', and the agreement that was reached is very revealing as to the range of resources that these moors offered. It was agreed that the portion of the moor that was not yet enclosed (implying that some reclamation had already occurred elsewhere) be divided in two parts of equal value, that nearer the Lichelak to be the dean's, and that nearer the watercourse called Padenesberthlak to be the abbot's. The abbot was permitted to maintain his weirs called Hachwere, Bordenewere and Pariswere and taking what he needed of the Dean's soil for that purpose. The abbot retained all the rights, including that of fishing in Meare Pool with the watercourse to Lichlake, although the dean and his tenants were allowed to water their cattle there and travel across the water by boat during daylight hours. The dean and the abbot also retained rights of turbary, cutting alders, piggeries, and common pasture for cattle, in each other's moors. The dean retained parcels of the moor previously enclosed within his manor of Mudgley.

This lengthy and detailed agreement did not, however, resolve the issue and in 1278 the abbot's men destroyed a piggery belonging to the dean in Godney Moor. ${ }^{113}$ By I283, the abbot consolidated his claim there, in exchange for relinquishing his interests east of the 'watercourse [the 'old Brue'] from Bleadney to Lineacre' (to the north of Garslade Farm). ${ }^{114}$ In I 3 I 5, however, the piggery at Godney was destroyed again along with a weir on the Hartlake, and the dean demolished some of the abbot's walls, dykes and sluices in Blackford and Mark Moors to the west of Wedmore. ${ }^{115}$ In 1326 Bishop Drokensford and Abbot Adam of Sodbury agreed to appoint three men to settle the disputed rights within the moors, but just four months later someone set fire to the abbot's peat moors between Burtle Priory and Glastonbury, threatening the Abbey itself. The bishop then excommunicated the abbot after four of his men allegedly destroyed buildings on his moor of Thealmoor [Tealham Moor]. ${ }^{116}$ In the following year the abbot was accused of burning the dean's timber and grass in Mudgley, and the dean of destroying houses at Meare and taking trees, I 2 horses, 6o oxen, 50 cows, ioo bullocks and Ioo pigs worth $£ 200 .{ }^{117}$ Such a state of affairs clearly could not continue and in 1327 it was agreed to divide the disputed moors into two parts, equal in value though not acreage, along a line running from Consailleswalle (south of Mudgley on the Isle of Wedmore) $)^{118}$ to 'the rhyne below Coubrugg [Cowbridge, and immediately south of the fen-edge at Mudgley along what is now called the Panborough Drain (SRO DD/ SAS PR 462). This is one of the very few moor boundary banks that is still visible: H. Hudson, 'Wedmore', 25 in I. Burrow, S. Minnitt and B. Murless (eds.), 'Somerset archaeology i 982', Proc. Somerset Archaeol. Nat. Hist. Soc., i 27 , I $3-3$ I.
} 
now Westhay Bridge] directly opposite the east corner of a close called Parismead below the hamlet of Westhay' (Fig. 3) with Glastonbury having Meare and Godney Moors to the east and the Dean and Chapter of Wells having Tadham Moor. ${ }^{19}$ Intercommoning, however, continued with the rights of tenants to common in the nearest moor being protected and certain of the dean and chapter's tenants in Mudgley, Mark and Wedmore still having unlimited rights of pasture in the abbot's moor at Godney, while both parties were allowed to have turbary, alders and piggeries in each other's half of the moors. ${ }^{120}$

In 1327 there was a second agreement covering the right of the Bishop's tenants in the manor of Wookey and its hamlets of Easton, Burcott, Polsham and Coxley (in the Sheppey Valley south-west of Wells) to have grazing in the abbot's moor at Godney. The abbot and his tenants at Meare, Bleadney, Panborough and Marchey were to have similar rights in the bishop's moors at Wookey, and each agreed that if the animals of the other strayed out of their respective moors they would not be impounded but driven back. To help define these rights, the watercourse through northern Godney Moor between Monkenmead (Hurn) and Bleadney was straightened and made $\mathrm{I} 2 \mathrm{ft}[3.7 \mathrm{~m}]$ wide, which each party was to maintain equally (Fig. $2 \mathrm{C}$ ). In I 352 a further agreement was reached over the division of rights in the moors north of Glastonbury between the Abbey and the Bishop of Wells, when the Hartlake River was straightened. ${ }^{121}$

\section{WILDFOWLING}

The disputes and agreements described above make reference to many of the rich wetland resources of this area, but there were others. The significance of wildfowling may be indicated by the place-name 'Henangre' west of Meare, henn suggesting wild bird, and anger suggesting pasture. ${ }^{122}$ Meare was the only place within the jurisdiction of Glastonbury Abbey to have a heronry at the time of the Dissolution, and the survey of I 539 includes rights to swans, herons and pheasants (see above); other references to the rights of wildfowling occur in the customs of Mudgley and Wookey. ${ }^{123}$

\section{PLANT RESOURGES}

The rich ecological mosaic of the Brue Valley backfens would have offered a wide range of plant resources for both human communities and grazing animals. A dispute of $\mathrm{I} 242 / 3$ illustrates some of the resources that were available, notably far more wet woodland than is present in the landscape today. The Abbot of Glastonbury complained that 4I men had by force of arms entered his moors at

\footnotetext{
119 G.C. I, No. I57; G.C. II, No. 645 and 647. Tadham Moor lay between Consailleswalle/Bounds Ditch to the east and Bounds Rhyne to the west. The modern Ordnance Survey maps incorrectly place Tealham Moor in this areas, below Lands End Farm and Heath House, whereas it actually lay to the west of Bounds Rhyne being the Moor belonging to the Bishop's manor of Blackford.

${ }^{120}$ G.C. II, No. 647; Wells I, 226-8; and see the I 557 Survey of Wookey in Hasler, op. cit. note Io9, 37.

${ }^{121}$ G.C.I, I6 1 ; Wells I, 324 .

122 I 30 I / 2 Meare Account Roll: SRO T/PH/Lon 2/I4 I I 272; A. H. Smith, English Place-Name Elements, Part I (Cambridge, I956), i I and 242.

${ }^{123} \mathrm{~J}$. Wiglesworth, 'The heronries of Somerset', Proc. Somerset Archaeol. Nat. Hist. Soc., 64 ( 1 9 18), 68-85; SRO DD/ SAS PR 462; Hasler and Luker, op. cit. in note 82.
} 
Godney and Bleadney and cut down trees. The men claimed they had rights of common in the moors for grazing their cattle, and collecting timber to repair bridges and sedges for fuel. ${ }^{124}$ Alderwoods are recorded in agreements of 1272 and I 327 over the rights in the moors between Meare and Mudgley, while in I 30 I / 2 a withy bed is recorded at Pokedhule. In the Beere Survey an alderwood is mentioned in the northern part of the moors north of Godney, while another wood, Fayebroke, is described as being on the northern bank of Ferlingmere (Meare Pool). Alderwood is also recorded close to the moor edge below Mudgley, on La Barges' around Barrow Hill in Panborough, and on Ash, Row and Knowle moors in the Axe Valley in Wookey, north of Bleadney. ${ }^{125}$

The I 26o Survey of Abbot Ford records the collecting of reeds from Meare, while the agreement by which the former Abbot Michael of Amesbury retired to Meare specified that the fishery of Meare and the entire reed-bed was retained by the current abbot, though Amesbury could take whatever reeds he needed for roofing his houses. ${ }^{126}$ John of Glastonbury (No. I I 5 ) also records the collecting of brushwood for fuel. Peat could also be burnt as fuel, though there are perhaps surprisingly few direct references to the right to cut peat ('turbary'). In I 272 there is reference to disputed rights of turbary in the moors between Meare and Mudgley, and in I529/30 there is reference to turbary in 'La Heath' (Meare Heath) south of the island. ${ }^{127}$ The reference to 'Lineacre' in 1283 , and indeed 'Liney' in Sowy to the south of the Polden Hills and 'Linmoor' in Wookey, implies the cultivation of flax on the moors. This was often grown on essentially unimproved marshlands due to the need for an abundant supply of water for retting. ${ }^{128}$

MEARE AND PATTERNS OF AGRIGULTURE ON GLASTONBURY'S SOMERSET MANORS

The agricultural use of the wetlands in Meare, both reclaimed and unreclaimed, must be seen in the context of the wider manorial economy of Glastonbury Abbey's estates. In terms of their physical topography Glastonbury's manors can be divided into three groups: firstly the mainly wetland manors centred on the islands of Meare with Godney, Brent and Sowy in the Somerset Levels; secondly the Polden Hills and other manors that were essentially dryland but which also extended into the unreclaimed raised bogs and fen-peat of the Brue Valley and Kings Sedgemoor; and thirdly the wholly dryland manors of southern and eastern Somerset. The pastoral element within the economies of the first two groups was dominated by cattle, while the dryland manors had sheep as a far greater proportion of the livestock. The essentially wetland manors had diverse cropping

\footnotetext{
${ }^{124}$ Chadwyke-Healey, op. cit. in note I I I, No. 572.

125 Beere, BL Egerton 3034, fo. I02; G.C. II, Nos. 478 and 647; Wells I, 50, 226-8; Williams, op. cit. in note 87, 29-32; SRO T/PH/Lon 2/ I 4 I I 272; Hudson, op. cit. in note 82, 93-5; Hasler, op. cit. note Io9, 37 and 58; idem and Luker, op. cit. in note $82,3 \mathrm{I}$.

${ }^{126}$ Ford, 205; 7. Glaston., No. I I 7 .

127 Wells I, 226-8; Meare Court Roll: SRO T/PH/Lon 2/30 I0757; Williams, op. cit. in note 88, 29.

${ }^{128}$ G.C. II, 643; I 262: Sowy Court Roll: SRO T/PH/Lon 10682 2/23; Hasler and Luker, op. cit. in note 82, map 6; M. C. Higham, 'Some evidence for i 2 th- and i 3 th-century linen and woollen textile processing', Medieval Archaeol., XXXIII ( 1989$), 3^{8-} 53$.
} 
regimes including a significant proportion of legumes, whereas the Polden Hills and wholly dryland manors were dominated by the extensive cultivation of wheat and to a lesser extent oats (all the arable on the Polden Hills was on the dryland component of the manors). These differences are also reflected in the demesne land-use c. I 30o: the Polden Hills and other fen-edge manors had on average $64 \%$ arable, $28 \%$ meadow and $5 \%$ pasture, whereas the wholly dryland manors averaged $69 \%$ arable, i $2 \%$ meadow and i $\%$ pasture. ${ }^{129}$ Meare, by contrast had $46 \%$ of its demesne sown as arable, $4 \mathrm{I} \%$ meadow and I $2 \%$ pasture, though in practice the area of pasture available was much larger with the abundance of grazing on the common moors and heaths (see above).

A distinctive element of the arable cultivation on those of Glastonbury's manors with the greatest area of wetland (Brent and Sowy, and to a lesser extent Baltonsborough) was the extraordinary proportion of demesne land sown with legumes, mainly beans (Tab. 4). Beans were sometimes grown for consumption by seigniorial households and agricultural workers, for sale, and in order to replenish the soil, and in these cases they can be regarded as a cereal crop. In other agricultural regimes, however, they were primarily grown for fodder, in which case they should be regarded as part of a pastoral regime. Such was the case on the Somerset Levels. The four manors with relatively high proportions of the demesne sown with beans (c. 40\% in Brent, Sowy and Baltonsborough; and I $00 \%$ in Withy), along with Meare and Godney (for which these cropping data are not available), also had Glastonbury's only significant herds of cattle, which were primarily for dairy production. The Abbey's only swineherds were at Baltonsborough, Brent, Meare/Godney, Sowy (the largest) and Walton, and the only horse studs were at Brent and Sowy.

Within the group of primarily wetland manors, the economy of Meare was particularly distinctive in that with Godney it had Glastonbury's major breeding herd of cattle. ${ }^{130}$ Over the period I $274^{-}$I 3 I 5 , for example, there were 56.7 calves born a year in Meare with Godney, compared to 32.9 in Baltonsborough, 29.6 in Brent and 20.0 in Sowy (other manors having c. 20 or fewer). Meare with Godney also had the largest dairy production of all Glastonbury's manors: in I 3 I I / I 2 , for example, it produced 63 I cheeses, compared to $35^{6}$ in Sowy, 329 in Baltonsborough and 276 in Brent (other manors having c. 240 or less). These other manors had far larger areas of dryland/reclaimed land than Meare, which once again serves to demonstrate that the unreclaimed heaths and moors around Meare and Godney must have provided excellent grazing land. This is reflected both in the lengthy series of disputes between Glastonbury and Wells, and in the series of droveways that can be identified within the historic landscape (Fig. IoA): reclamation was not required for a successful pastoral economy.

\section{CONGLUSIONS}

In this paper, the way in which one particular monastery, Glastonbury Abbey, manipulated its environment has been explored as a contribution to understanding

\footnotetext{
129 Keil, op. cit. in note 16,75 .

${ }^{130}$ Ecclestone, op. cit. in note i 6 , tabs. I ic and I Im.
} 
TABLE 4

PERGENTAGE OF THE DEMESNE SOWN WITH LEGUMES, WHEAT AND

OATS ON GLASTONBURY ABBEY'S SOMERSET MANORS IN I 334 (after Keil, op. cit. note I6, tab. I 2)

\begin{tabular}{llll}
\hline & legumes & wheat & oats \\
\hline Godney & No data & No data & No data \\
Meare & No data & No data & No data \\
Brent & 45 & I 8 & 38 \\
Sowy & 33 & 3 I & o \\
Polden Hills & & & \\
Ashcott & 3 & 82 & I 5 \\
Greinton & 2 & 86 & 9 \\
Shapwick & 2 & 8 I & I 6 \\
Street & 4 & 75 & I \\
Walton & o & 74 & 22 \\
Other manors extending on to the Levels & & & \\
Baltonsborough & 23 & 30 & 2 I \\
Butleigh & No data & No data & \\
Glastonbury & 9 & 62 & I 3 \\
High Ham & I & 80 & I 7 \\
Eastern/southern Somerset & & & \\
Batcombe & I & 53 & 43 \\
Ditcheat & 3 & 79 & I \\
Doulting & o & I I & 84 \\
East Pennard & o & 70 & 30 \\
Marksbury & 2 & 75 & I 7 \\
Mells & o & 47 & 44 \\
Pilton & o & 62 & 36 \\
Podimore Milton & I & 49 & \\
Wrington & 2 & 85 & I o \\
\hline
\end{tabular}

the increasing intensity with which the English landscape was exploited during the medieval period. Key to this has been the careful integration of topographical information contained within the Abbey's rich historical records, with what survives of the physical fabric of the medieval landscape as preserved within the 'historic landscape' of today. Buried archaeology, standing buildings, palaeoenvironmental material, and place-name evidence have added to the story.

At the time of the Dissolution in I 539, Glastonbury Abbey was the wealthiest monastery in the country, and this prosperity reflects the extent and effective management of its resources. In part, these 'resources' were the material product of agriculture, along with the exploitation of natural resources such as Meare Pool, and the modification of the landscape for example through the canalization of rivers. Other 'resources' were less tangible: Glastonbury was a major centre of pilgrimage and was a great 'marshaller of antiquity', ${ }^{131}$ most famously illustrated

${ }^{131}$ Crick, op. cit. in note 44 . 
by the 'discovery' of the bodies of Arthur and Guinevere in I I I soon after a disastrous fire left the monks in need of some quick cash. A century earlier the monks had moved the bones of St Begninus from the small island of Meare to the Abbey itself which may represent an earlier example of exploiting (or partially creating?) history for material ends. The islands west of Glastonbury clearly had a special significance. Glastonbury lies at the end of a promontory that projects into, and dominates, the eastern end of the Somerset Levels that formed part of the Abbey's earliest estates. That what were to become the 'Twelve Hides' contained such vast expanses of wetland suggests that their value was not simply viewed in terms of their agricultural potential (which at that time would have been low): the association of each of the 'islands' and a number of promontories within this part of the Somerset Levels with early religious sites suggests that this was a landscape which possessed, or was given, great symbolic significance. This too was exploited and managed by the monastic community.

Despite its strongly wetland character, many of the trends in landscape utilization seen in Meare form part of the wider trend towards an increasing intensity of landscape exploitation in the late ist millennium A.D. The planned village and its open fields appear to have been in place by the late i oth century, as was the case at Shapwick and the other Polden Hills manors. It was also about this time that landscapes may have been similarly reorganized on Wedmore and more widely in Central/South-East Somerset, and this expansion of arable cultivation/ change in agricultural practice may in turn have led to increased sedimentation within the rivers that flowed from the drylands around Glastonbury. In the postConquest period, wetlands around the northern side of the island were drained, reflecting the agricultural expansion of the I 2 th and I $3^{\text {th centuries, and these areas }}$ of predominantly meadow helped support what was, by c. I 300, Glastonbury Abbey's most successful pastoral economy. The remaining wetland areas were, however, far from being regarded as 'waste' and were clearly highly valued during the High Middle Ages: the Abbot of Glastonbury was even excommunicated as he battled to maintain his rights there! At a time when population and grain prices were high, the fact that such large areas remained unreclaimed itself suggests that resources such as fishing, wildfowl, reeds, alder woodland and particularly grazing were perceived as providing a respectable level of productivity. It may, however, have been the emphasis on pastoralism that lessened the pressure to enclose and drain the remaining areas of moor, as these were also clearly extensively grazed, notably by cattle and pigs. Finally, the significance of Meare is reflected in the high levels of investment in its church and manorial complex, and the fact that it was a favourite residence of several abbots, notably Sodbury (1323-34) and Amesbury (upon his retirement in I252). Far from 'making the most of a bad situation', Meare, set within its extensive wetlands, was one of Glastonbury's most important manors.

\section{ACKNOWLEDGEMENTS}

The author is extremely grateful to Mick Aston, James Bond, David Hall, Hazel Hudson and Frances Neal for commenting upon an earlier draft of this paper, and to Richard Brunning, Martin Ecclestone, Charles and Nancy Hollinrake, Frances Neale, 
David Musgrove, Jane Penoyre of the Somerset Vernacular Building Research Group, and Cressida Whitton and Steve Reed of Exeter Archaeology for supplying unpublished information. I would particularly like to thank Hazel Hudson for supplying a translation of the I $55^{8}$ perambulations of the bounds of the manor of Mudgley (SRO DD/SAS PR 462). 